\title{
Palaeo-ice stream pathways and retreat style in the easternmost Amundsen Sea Embayment, West Antarctica, revealed by combined multibeam bathymetric and seismic data
}

\author{
J.P. Klages ${ }^{\text {a,* }}$, G. Kuhn ${ }^{\text {a }}$, A.G.C. Graham ${ }^{\text {c }}$, C.-D. Hillenbrand ${ }^{\text {b }}$, J.A. Smith ${ }^{\text {b }}$, F.O. Nitsche ${ }^{\text {d }}$, R.D. Larter ${ }^{\text {b }}$, K. Gohl ${ }^{\text {a }}$ \\ a Alfred-Wegener-Institut, Helmholtz-Zentrum für Polar- und Meeresforschung, Marine Geosciences, Am Alten Hafen 26, 27568 Bremerhaven, Germany \\ ${ }^{\mathrm{b}}$ British Antarctic Survey, High Cross, Madingley Road, Cambridge CB3 OET, United Kingdom \\ c College of Life and Environmental Sciences, University of Exeter, Amory Building, Rennes Drive, Exeter EX4 4RJ, United Kingdom \\ ${ }^{\mathrm{d}}$ Lamont-Doherty Earth Observatory of Columbia University, 61 Route 9W, Palisades, NY 10964, USA
}

\section{A R T I C L E I N F O}

\section{Article history:}

Received 20 January 2015

Received in revised form 19 May 2015

Accepted 21 May 2015

Available online 24 May 2015

\section{Keywords:}

West Antarctic Ice Sheet

Glacial landforms

Subglacial geology

Basal thermal regime

Ice streams

Inter-ice stream ridge

Ice sheet retreat

Grounding-zone wedge

Abbot Ice Shelf

\begin{abstract}
A B S T R A C T
Multibeam swath bathymetry data sets collected over the past two decades have been compiled to identify palaeo-ice stream pathways in the easternmost Amundsen Sea Embayment. We mapped 3000 glacial landforms to reconstruct ice flow in the $\sim 250-\mathrm{km}$-long cross-shelf Abbot Trough. This bathymetric feature was occupied by a large ice stream, which was fed by two tributaries (Cosgrove and Abbot) and reached the continental shelf edge during the last maximum ice sheet advance. Geomorphological mapping has enabled a clear differentiation between subglacial landforms indicating warm- (e.g., megascale glacial lineations) and cold-based (e.g., hill-hole pairs) ice conditions on the continental shelf during the last glaciation. Grounding-zone wedges and recessional moraines, mapped within the palaeo-ice stream troughs and on adjacent sea-floor highs (referred to as inter-ice stream ridges) indicate grounding line stillstands or re-advances of the West Antarctic Ice Sheet during the last deglaciation of the shelf. We observe that the locations of grounding-zone wedges coincide with trough constrictions as well as local topographic highs of harder substrate. This combination of trough 'bottlenecks' and local pinning points on an otherwise retrograde slope is likely to have modified the pace of grounding-line retreat, causing the grounding zone to pause and deposit grounding-zone wedges. The episodic retreat recorded within Abbot Trough corresponds to post-glacial episodic retreat interpreted for the neighbouring Pine Island-Thwaites palaeo-ice stream trough, thus suggesting a uniform pattern of retreat across the eastern Amundsen Sea Embayment. Locally, indications are strong that a change in basal thermal regime of the ice from warm- to cold-based conditions occurred prior to final retreat, as hill-hole pairs overprint megascale glacial lineations. Further, the correlation of grounding-zone wedges with geological boundaries emphasises the influence of subglacial geology on ice stream flow. Our new geomorphological map of the easternmost Amundsen Sea Embayment resolves the pathways of palaeo-ice streams that were probably all active during the last maximum extent of the ice sheet, and the extent of adjacent inter-ice stream ridges. It reveals information about the style of, and the basal thermal regime during, the subsequent grounding line retreat. Such information provides an important empirical framework by which the accuracy of ice sheet models can be gauged.
\end{abstract}

(C) 2015 Elsevier B.V. All rights reserved.

\section{Introduction}

Ice streams are key arteries of the Antarctic Ice Sheet draining large amounts of ice from the continent's interior toward the ocean (e.g. Rignot et al., 2008, 2011). Dramatic changes in West Antarctic ice streams - such as major thinning, flow acceleration, and grounding line retreat - have recently been observed, leading to concerns over future changes and their contribution to sea level rise (e.g., Vaughan, 2008; Pritchard et al., 2009, 2012; Tinto and Bell, 2011; Favier et al. 2014; Joughin et al., 2014; Rignot et al., 2014). The complex and

\footnotetext{
* Corresponding author.

E-mail address: Johann.Klages@awi.de (J.P. Klages).
}

nonlinear behaviour of ice streams suggests that the contemporary observational record spanning only the last two to three decades cannot fully elucidate processes controlling long-term ice stream behaviour (i.e., over centuries to millennia; Jamieson et al., 2014). Therefore, numerical simulations of ice sheet changes over longer timescales (i.e., from the last glacial period throughout the deglaciation until present) are required to (i) better understand ice stream behaviour and (ii) predict future changes more precisely, after reliably simulating past ice sheet configurations known from empirical records. Reconstructions of ice flow extent (especially ice stream width and bed topography) and the history of grounded ice retreat from geological and geophysical data provide key constraints for validating these numerical models. While some models reconstructing the ice sheet configuration at the 


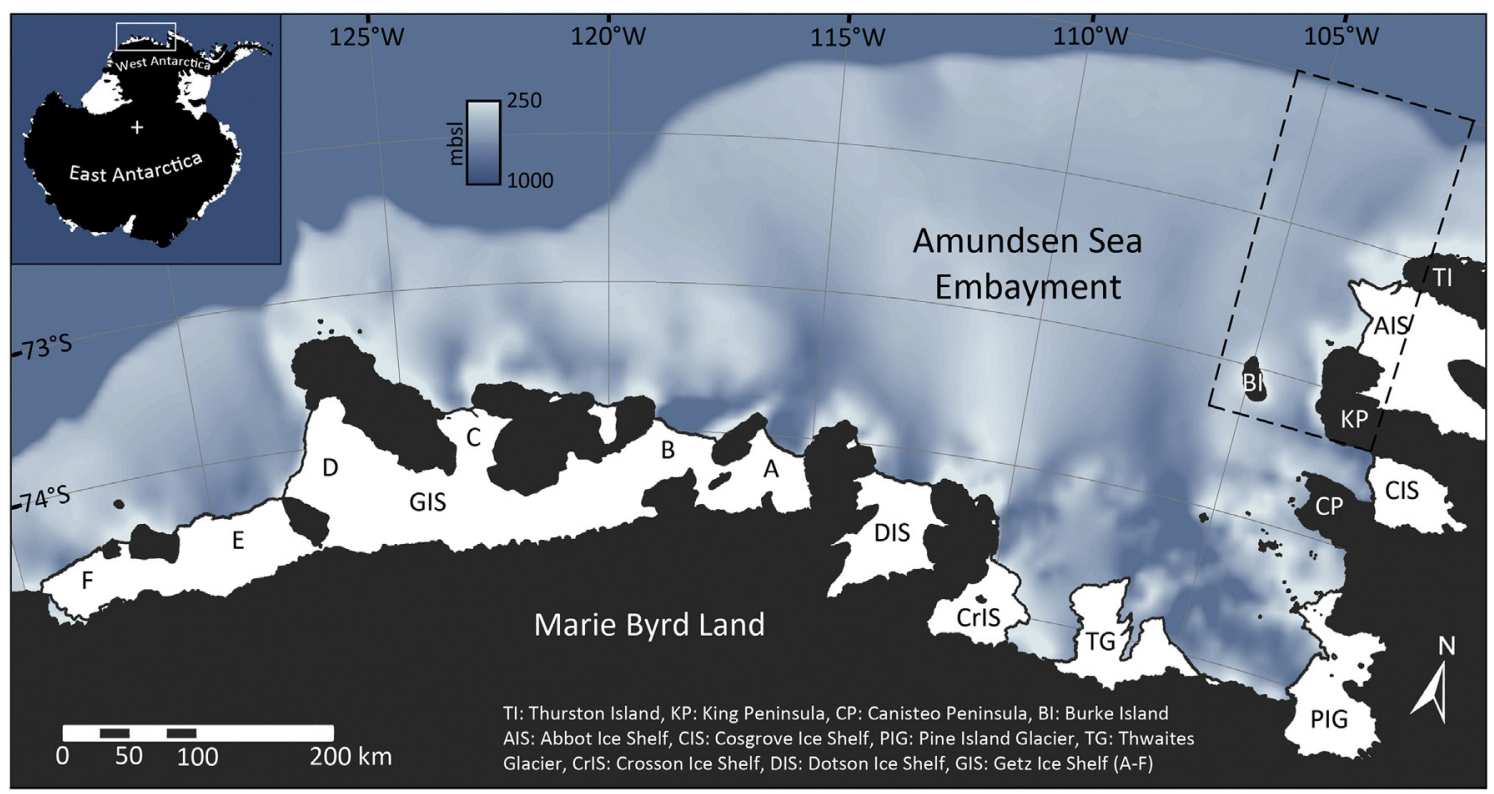

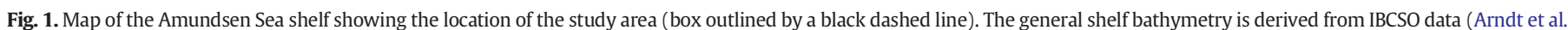

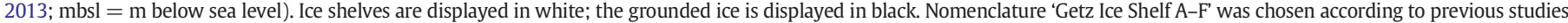
(Larter et al., 2009; Hillenbrand et al., 2013; Klages et al., 2014). Abbreviations for the main geographical features are explained in the figure.

Last Glacial Maximum (LGM; 23-19 cal. ka BP - calibrated kiloyears before present) have already included geological data (e.g., LeBrocq et al., 2011; Golledge et al., 2013, 2014; Jamieson et al., 2014), gaps are still significant in understanding West Antarctic Ice Sheet (WAIS) behaviour (e.g., Larter et al., 2014; The RAISED Consortium, 2014).

\subsection{Study area and previous work}

One area where modern-day changes are most rapid and palaeoreconstructions are urgently required is the Amundsen Sea drainage sector of the WAIS (Fig. 1). Current LGM model simulations capture the locations and widths of palaeo-ice streams on the inner and middle shelf as mapped from bedforms (e.g., Larter et al., 2009; Nitsche et al., 2013), but considerable data-model mismatches remain on the outer shelf (Golledge et al., 2013, 2014). On the outer shelf of the eastern Amundsen Sea Embayment (ASE) in particular, model results reconstructing the widths of fast-flowing corridors deviate significantly from existing data constraints. This reflects critical gaps in the coverage of geological and geophysical data in this area (e.g., Larter et al., 2014), which hampers detailed reconstructions of former ice flow. Available data suggests that ice flowed at different times within two outer shelf outlets that form branches emanating from the main Pine IslandThwaites palaeo-ice stream trough (PIT), which in turn, extends from the modern fronts of Pine Island and Thwaites Glaciers seaward toward the outer shelf (Fig. 1) (Evans et al., 2006b; Graham et al., 2010; Jakobsson et al., 2012). Graham et al. (2010) concluded that prior to the end of the LGM, the eastern rather than the western branch was the major pathway of the ice stream as subglacial landforms indicative of fast ice flow on its bed are more pronounced and better preserved than in the western branch. Thus, a younger age for the bedforms in the eastern branch has been suggested. Graham et al. (2010) further concluded that the ice stream reached at least to within $68 \mathrm{~km}$ of the shelf edge (presence of megascale glacial lineations) but probably occupied the trough all the way to the shelf edge, as a trough mouth depression is visible here. Iceberg furrows probably eradicated any potential preexisting lineations.

Limited data exist from the middle and outer shelf regions east of the main PIT. Kellogg and Kellogg (1987) first described a 'narrow, relatively shallow trough' seaward of the Abbot Ice Shelf (Fig. 1), but it remained unclear whether or not this trough extended to the shelf edge.
Furthermore, these authors proposed the presence of a smaller ice stream that may have occupied Ferrero Bay, offshore from the Cosgrove Ice Shelf (Fig. 1). Nitsche et al. (2007) provided the first comprehensive compilation of ASE bathymetry data that confirmed the presence of a small trough extending from the Cosgrove Ice Shelf along the southern coast of King Peninsula as well as a seafloor depression NW of Thurston Island (Fig. 1). However, because of insufficient coverage of highresolution multibeam swath bathymetry data, a possible inner to outer shelf connection of these depressions remained undetermined. More recently, Hochmuth and Gohl (2013) concluded coalescing palaeo-ice streams emanating from the modern Cosgrove and Abbot ice shelves based on seismic reflection data from the shelf between Burke Island and King Peninsula (cf., Uenzelmann-Neben et al., 2007) and that the Abbot-Cosgrove palaeo-ice stream merged on the outer shelf with an additional, NNE-ward directed branch of the Pine Island-Thwaites palaeo-ice stream during past glacial maxima. However, until now geomorphological evidence to validate these reconstructions has been lacking, primarily because of an absence of seafloor morphological data that resolves subglacial bedforms and thus allows palaeoice flow pathways to be reconstructed.

Here we present a comprehensive swath-bathymetric data set from the middle and outer shelf of the easternmost ASE (between $106^{\circ} \mathrm{W}$ and $101^{\circ} \mathrm{W}$ and $\sim 71^{\circ} \mathrm{S}$ and $73^{\circ} 22^{\prime}$ S; Fig. 2), which we used to develop a new geomorphological map of this hitherto poorly studied part of the ASE shelf (Fig. 3). The map improves the understanding of the pathways and configuration of past ice streams in Abbot Trough (AT).

\section{Material and methods}

The marine geophysical data used in this study were acquired during 11 scientific cruises to the ASE between 1994 and 2013. All cruises, including acquisition systems and methods, are summarized in Table 1. All bathymetry data sets were derived from ship-borne multibeam echo sounders. Depth values and beam ray paths of the bathymetric data were calibrated during each individual cruise using sound velocity profiles from conductivity-temperature-depth (CTD) and expendable bathymetry thermograph (XBT) measurements and/or the systems' own cross-fan calibration. Subsequently the data were ping edited, processed, compiled, and gridded as a single data set with a $30 \times 30 \mathrm{~m}$ 


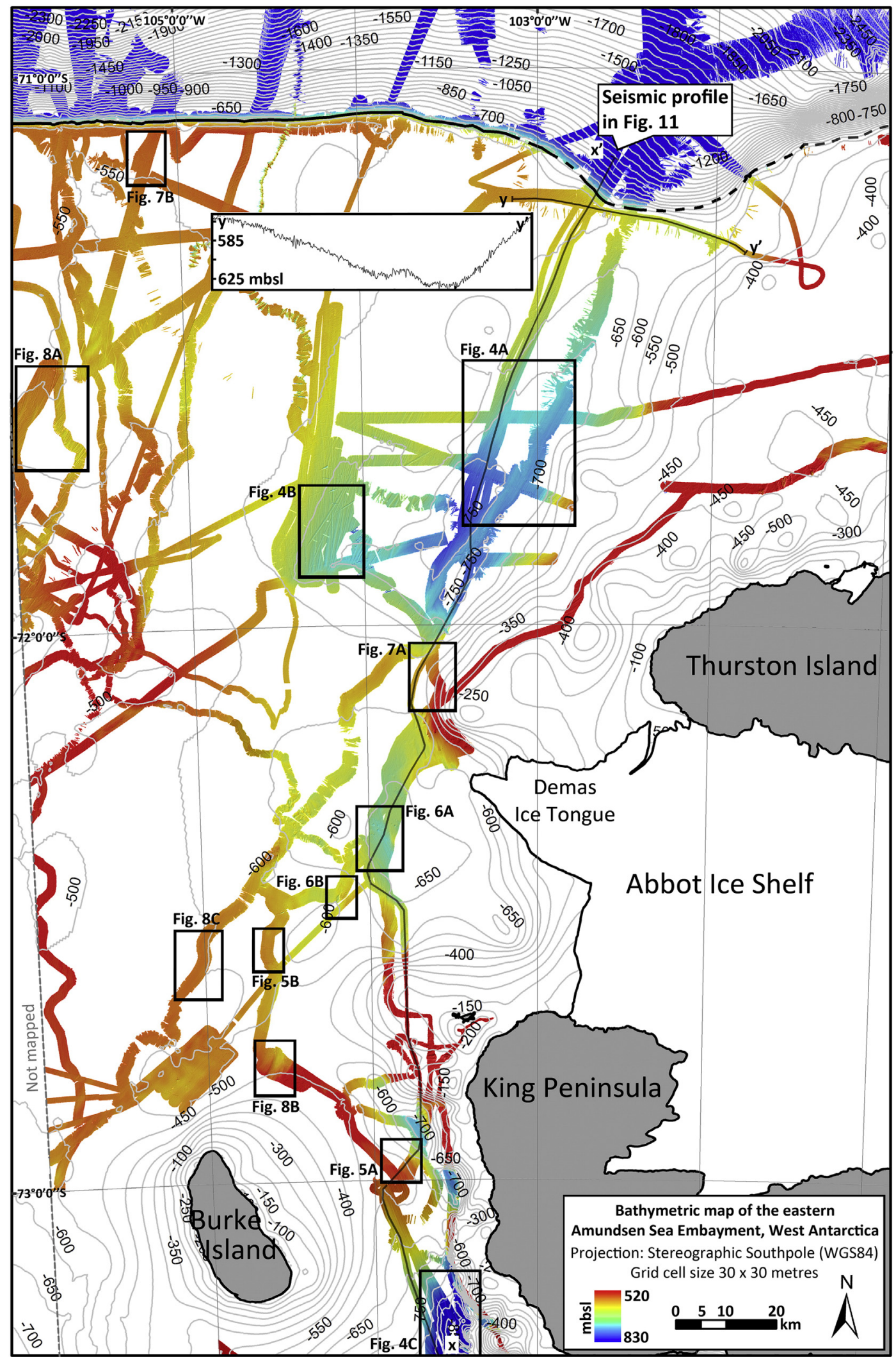

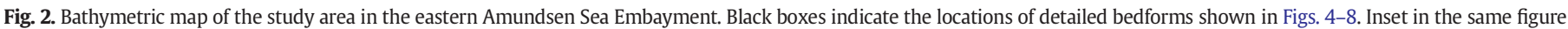

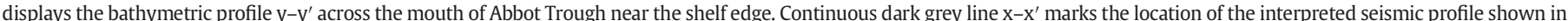

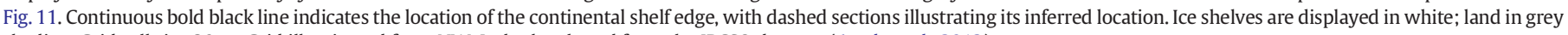
shading. Grid cell size $30 \mathrm{~m}$. Grid illuminated from NW. Isobaths plotted from the IBCSO data set (Arndt et al., 2013). 


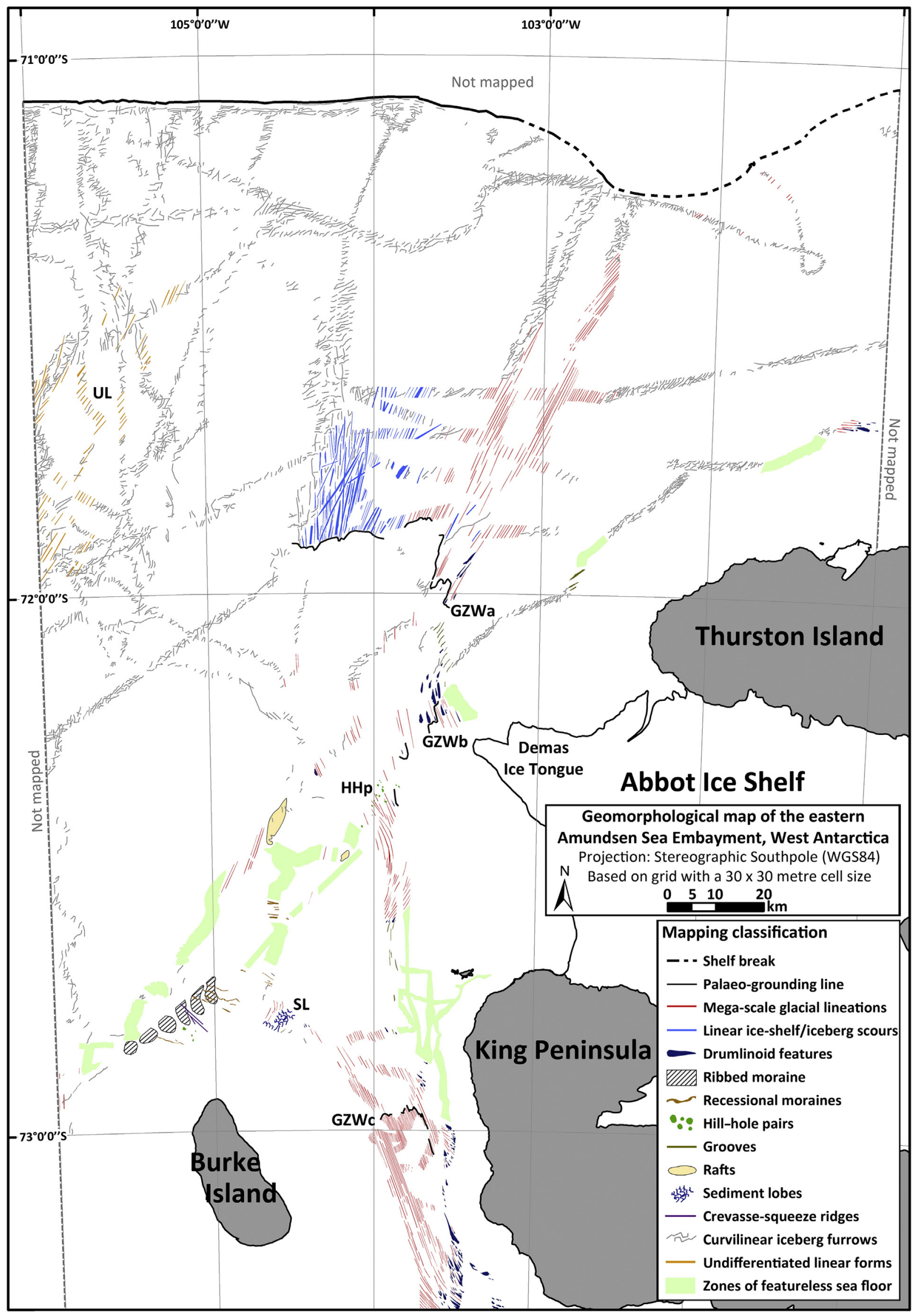

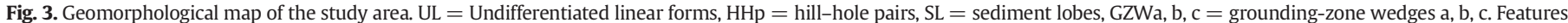
digitized from the 30-m swath bathymetric grid shown in Fig. 2. 
Table 1

Bathymetry, sub-bottom profiler and seismic data sets.

\begin{tabular}{|c|c|c|c|c|c|}
\hline Cruise (year) & Vessel & Method & System & $\begin{array}{l}\text { Principal } \\
\text { investigator/operator }\end{array}$ & Reference/data access \\
\hline ANT-XI/3 (1994) & RV Polarstern & Swath bathymetry & Atlas Hydrosweep DS-1 & Miller, H & Miller and Grobe, (1996)/www.pangaea.de \\
\hline ANT-XXIII/4 (2006) & RV Polarstern & Swath bathymetry & Atlas Hydrosweep DS-2 & Schenke, HW & Gohl (2007)/www.pangaea.de \\
\hline ANT-XXIII/4 (2006) & RV Polarstern & Sediment echosounding & Atlas PARASOUND P70 & Kuhn, G & Gohl (2007)/www.pangaea.de \\
\hline ANT-XXIII/4 (2006) & RV Polarstern & $\begin{array}{l}\text { Multi-channel } \\
\text { reflection seismics }\end{array}$ & $\begin{array}{l}\text { Sercel GI-Gun with Sercel } \\
\text { Sentinel/Prakla streamer }\end{array}$ & Gohl, K. & Gohl (2007) \\
\hline ANT-XXVI/3 (2010) & RV Polarstern & Swath bathymetry & Atlas Hydrosweep DS-2 & Schenke, HW & Gohl (2010)/www.pangaea.de \\
\hline ANT-XXVI/3 (2010) & RV Polarstern & Sediment echosounding & Atlas PARASOUND P70 & Kuhn, G & Gohl (2010)/www.pangaea.de \\
\hline ANT-XXVI/3 (2010) & RV Polarstern & $\begin{array}{l}\text { Multi-channel } \\
\text { reflection seismics }\end{array}$ & $\begin{array}{l}\text { Sercel GI-Gun with Sercel } \\
\text { Sentinel/Prakla streamer }\end{array}$ & Gohl, K. & Gohl (2010) \\
\hline NBP0001 (2000) & RV Nathaniel B. Palmer & Swath bathymetry & SeaBeam 2012 & Jacobs, S & Carbotte et al. (2007)/www.marine-geo.org \\
\hline NBP0702 (2007) & RV Nathaniel B. Palmer & Swath bathymetry & Kongsberg EM 120 & Jacobs, S & -/www.marine-geo.org \\
\hline NBP0901 (2009) & RV Nathaniel B. Palmer & Swath bathymetry & Kongsberg EM 120 & Jacobs, S & -/www.marine-geo.org \\
\hline NBP1210 (2013) & RV Nathaniel B. Palmer & Swath bathymetry & Kongsberg EM 120 & $\begin{array}{l}\text { United States Antarctic } \\
\text { Program (USAP) }\end{array}$ & -/www.marine-geo.org \\
\hline JR84 (2003) & RRS James Clark Ross & Swath bathymetry & Kongsberg EM 120 & Jenkins, A & -/http://geoportal.nerc-bas.ac.uk/GDP/ \\
\hline JR141 (2006) & RRS James Clark Ross & Swath bathymetry & Kongsberg EM 120 & Larter, RD & -/http://geoportal.nerc-bas.ac.uk/GDP/ \\
\hline OSO0910 (2010) & IB Oden & Swath bathymetry & Kongsberg EM 122 & $\begin{array}{l}\text { Jakobsson, M; } \\
\text { Anderson, J; Nitsche, FO }\end{array}$ & $\begin{array}{l}\text { Anderson et al. (2010)/http://oden.geo.su.se/ } \\
\text { OSO0910.php }\end{array}$ \\
\hline OSO0708 (2007) & IB Oden & Swath bathymetry & Kongsberg EM 120 & Jakobsson, M & -/http://oden.geo.su.se/OSO0708.php \\
\hline
\end{tabular}

cell size. The grid was visualized in ArcGIS 10 and glacial landforms were manually identified and mapped using criteria established by other workers (e.g., Graham et al., 2009; Livingstone et al., 2013; specified in Table 2).

In order to provide context to the landforms mapped on the seabed and to reveal information on the substrate geology, multibeam bathymetric data were supplemented by acoustic sub-bottom profiler data (PARASOUND; Table 1) and multichannel reflection seismic data collected on RV Polarstern cruises ANT-XXIII/4 and ANT-XXVI/3 (Gohl, 2007, 2010).

\section{Results and interpretation}

\subsection{Large-scale bathymetry of the study area}

The study area encompasses the $\sim 250$-km-long AT that extends from SW of King Peninsula in a northward direction along ca. $104^{\circ} \mathrm{W}$ (Fig. 2). Northwest of the Demas Ice Tongue, AT arcs NE-ward and reaches the shelf edge between $102^{\circ} \mathrm{W}$ and $103^{\circ} \mathrm{W}$ (Fig. 2, inset in the same figure). The trough deepens inland on the outer shelf but is shallower WNW of the Demas Ice Tongue as well as W and NW of King Peninsula, and is characterised by considerable changes in its width along its long axis ( $\sim 5$ to $\sim 35 \mathrm{~km})$. Shallow shelf regions (400-500 $\mathrm{m}$ below sea level ( $\mathrm{m}$ b.s.l. )) that flank AT to the east probably correspond to westward submarine extensions of King Peninsula and Thurston Island. In the west AT is flanked by a seafloor high $(\sim 500$ $600 \mathrm{~m}$ b.s.l.) that emanates from Burke Island in a northward direction and forms a ridge that separates the trough from PIT. The AT reaches its greatest water depths south of $73^{\circ} \mathrm{S}(\sim 900 \mathrm{~m}$ b.s.l. $)$ and north of $72^{\circ} \mathrm{S}$ ( $760 \mathrm{~m}$ b.s.l.). At the shelf edge, the floor of AT has a water depth of $625 \mathrm{~m}$ b.s.l., which is $~ 60 \mathrm{~m}$ deeper than on either side of the trough (Fig. 2, inset in the same figure).

\subsection{Seabed landforms}

The AT and the shallower inter-ice stream regions on either side display a wide range of landforms of glacial origin indicating the former presence of a grounded ice sheet. Based on the bathymetric map (Fig. 2) and the criteria listed in Table 2, we identified and mapped individual glacial landforms within AT and on the shallow trough flanks and combined them in a landform map (Fig. 3). The shallow shelf area north of Burke Island was previously interpreted as an 'inter-ice stream ridge' (Klages et al., 2013), and here we also apply this interpretation to the other seafloor highs flanking AT. The distribution, abundance, and morphologic characteristics (e.g., orientation, water depth distribution, etc.) of each feature class listed in Table 2 are used to establish their genesis. Visualisations and cross-sectional profiles help define each feature.

\subsubsection{Megascale glacial lineations (MSGLs)}

In total 592 megascale glacial lineations (MSGLs) were mapped in the study area. They are characterised by (i) high elongation, (ii) ridge-groove topography, (iii) parallel alignment, (iv) close proximity, and $(v)$ occurrence in sets typical of other MSGL bedform assemblages (e.g., Clark, 1993, 1999; Clark et al., 2003; Table 2). The most prominent and complete sets of MSGLs are situated in the south of AT between Burke Island and King Peninsula (mapped on Figs. 2, 3), where they are SSE-NNW-oriented, and NNW of the Demas Ice Tongue where they are SSW-NNE oriented. This northern MSGL set exhibits elongation ratios of up to $~ 70: 1$ and amplitudes of $1-6 \mathrm{~m}$ (Fig. 4A). The southern set contains the longest mapped MSGLs with maximum elongation ratios of up to 100:1 and amplitudes of 4-15 m. Directly WSW of the Demas Ice Tongue, a third set of less elongate MSGLs is mapped (elongation ratios up to 40:1). These MSGLs are sinuous and parallel, and record SSW-NNE to SSE-NNW flow through a curved trough. Small clusters with a northerly orientation are observed north of Burke Island on the outer shelf and between the three prominent MSGL sets (Fig. 3). A small single cluster of EW-oriented MSGLs is identified north of Thurston Island, directly west of $101^{\circ} \mathrm{W}$ (Fig. 3).

The vast majority of MSGLs are situated within the deepest part of AT along its central axis (Figs. 2, 3). The MSGLs extend northward to within $\sim 10 \mathrm{~km}$ of the shelf edge where they become increasingly overprinted by curvilinear iceberg furrows. The MSGLs with high elongations are a reliable indicator for ice-sheet grounding and fast ice flow, usually facilitated by a several-metre-thick unit of water-saturated deformable till or by basal sliding on a thin deformable sedimentary layer on top of a harder substrate (e.g., King et al., 2009, and references therein).

\subsubsection{Linear iceberg/ice shelf scours}

We mapped 117 S-N to SSW-NNE oriented linear scours that are restricted to the southward-dipping outer shelf section of AT north of $72^{\circ} \mathrm{S}$ (Fig. 4B, mapped on Figs. 2, 3). They occur in water depths between $\sim 640$ and $720 \mathrm{~m}$ b.s.l., point into shallower water at their northern end, and at their southern end they appear buried by sediments. The scours are distinct from nearby MSGLs because they are V-shaped, flanked by prominent lower-amplitude berms on either side (Fig. 4B, profile $\mathrm{x}-\mathrm{X}^{\prime}$; Table 2 ), and exhibit slightly different directions. The longest scour is $\sim 22 \mathrm{~km}$ long and $\sim 750 \mathrm{~m}$ wide. 
Table 2

Criteria for differentiating landforms.

\begin{tabular}{|c|c|c|c|c|c|}
\hline $\begin{array}{l}\text { Interpreted feature name/GIS } \\
\text { mapping classification (Fig. 3) }\end{array}$ & Description (non-genetic) & Dimensions min. (max.) L-W-H & Genetic interpretation & Figure reference & Literature reference \\
\hline Megascale glacial lineations (MSGL) & $\begin{array}{l}\text { Highly linear and parallel ridge-groove sets with } \\
\text { elongation ratios (L:W) of }>10: 1 \text {, usually } \\
\text { formed in soft till }\end{array}$ & $3 \mathrm{~km}-100 \mathrm{~m}-1 \mathrm{~m}(27.5 \mathrm{~km}-360 \mathrm{~m}-15 \mathrm{~m})$ & $\begin{array}{l}\text { Combined erosional/depositional origin } \\
\text { through grooving and ploughing of a } \\
\text { fast-flowing ice stream base on deformable } \\
\text { substrate (soft till) }\end{array}$ & Fig. $4 \mathrm{~A}$ & $\begin{array}{l}\text { Marguerite Trough } \\
\text { (Ó Cofaigh et al., } \\
\text { 2002, Fig. 2E) }\end{array}$ \\
\hline Linear ice-shelf/iceberg scours & $\begin{array}{l}\text { Parallel to sub-parallel highly linear v-shaped } \\
\text { scours with parallel ridges on either side, often } \\
\text { cross-cut by other scours }\end{array}$ & $4.5 \mathrm{~km}-60 \mathrm{~m}-5 \mathrm{~m}(22 \mathrm{~km}-900 \mathrm{~m}-18 \mathrm{~m})$ & $\begin{array}{l}\text { Linear scouring of the seabed through the keels } \\
\text { of an ice shelf or large tabular icebergs } \\
\text { (restricted in motion), scoured material } \\
\text { re-deposited as berms on either side of scour }\end{array}$ & Fig. 4B & $\begin{array}{l}\text { Filchner Trough } \\
\text { (Larter et al., 2012, } \\
\text { Fig. 4A) }\end{array}$ \\
\hline Drumlinoid features & $\begin{array}{l}\text { Streamlined, attenuated, oval-shaped hills with } \\
\text { tear-drop shaped heads }\end{array}$ & $650 \mathrm{~m}-230 \mathrm{~m}-15 \mathrm{~m}(6.2 \mathrm{~km}-1.1 \mathrm{~km}-200 \mathrm{~m})$ & $\begin{array}{l}\text { Flow across and erosion of resistant subglacial } \\
\text { material with sediment deposition and } \\
\text { formation of a tail that is attenuated and points } \\
\text { into the direction of palaeo-ice flow }\end{array}$ & Fig. $4 \mathrm{C}$ & $\begin{array}{l}\text { Western Amundsen } \\
\text { Sea Embayment } \\
\text { (Graham et al., } \\
\text { 2009, Fig. 7) }\end{array}$ \\
\hline $\begin{array}{l}\text { Grounding-zone wedges (GZW) - } \\
\text { only crest-line of GZWs mapped as } \\
\text { 'Palaeo-grounding line' }\end{array}$ & $\begin{array}{l}\text { Wedges with gently rising stoss-sides and } \\
\text { steeply dipping, sinuously-shaped lee-sides, } \\
\text { lineations on top terminate at the wedge crest }\end{array}$ & $\begin{array}{l}\geq \sim 25 \mathrm{~km}-\geq 11 \mathrm{~km}-14 \mathrm{~m} \\
(\sim 28 \mathrm{~km}-\geq 35 \mathrm{~km}-100 \mathrm{~m})\end{array}$ & $\begin{array}{l}\text { Sediment deposition at a palaeo-ice stream } \\
\text { terminus during stillstand or re-advance, } \\
\text { subglacial till deposition - proglacial debris } \\
\text { flow deposition on lee-side (foresets), lee side } \\
\text { points in direction of former ice flow }\end{array}$ & Fig. 5A & $\begin{array}{l}\text { Eastern Ross Sea } \\
\text { (Bart and Owolana, } \\
\text { 2012, Fig. 5) }\end{array}$ \\
\hline Ribbed moraines & $\begin{array}{l}\text { Large-scale hummocks with regular spacing } \\
(\lambda \sim 4 \mathrm{~km}) \text {, similar heights and close spatial } \\
\text { relationships }\end{array}$ & $3.2 \mathrm{~km}-\sim 3.3 \mathrm{~km}-20 \mathrm{~m}(4.5 \mathrm{~km}-\sim 3.3 \mathrm{~km}-25 \mathrm{~m})$ & $\begin{array}{l}\text { Relict moraines deposited beneath a } \\
\text { slow-flowing ice sheet through the organisation } \\
\text { of till transverse to flow }\end{array}$ & $\begin{array}{l}\text { see Fig. } 3 \text { in Klages } \\
\text { et al. (2013) }\end{array}$ & $\begin{array}{l}\text { Former Irish Ice } \\
\text { Sheet (Clark and } \\
\text { Meehan, 2001, Fig. 4) }\end{array}$ \\
\hline Recessional moraines & $\begin{array}{l}\text { Linear to curvilinear ridges with steep } \\
\text { stoss-flanks }\left(\sim 9^{\circ}\right) \text { and gentle lee-flanks }\left(\sim 3^{\circ}\right)\end{array}$ & $\sim 1 \mathrm{~km}-80 \mathrm{~m}-3 \mathrm{~m}(\sim 6 \mathrm{~km}-250 \mathrm{~m}-15 \mathrm{~m})$ & $\begin{array}{l}\text { Proglacial pushing/squeeze-out of originally } \\
\text { subglacially deposited debris along the } \\
\text { grounding line during minor halts or } \\
\text { re-advances of the ice sheet, stoss flank points } \\
\text { upstream }\end{array}$ & $\begin{array}{l}\text { Fig. } 5 \text { B; see also } \\
\text { Fig. } 3 \text { in Klages } \\
\text { et al. (2013) }\end{array}$ & $\begin{array}{l}\text { NE Greenland shelf } \\
\text { (Winkelmann et al., } \\
\text { 2010, Fig. 2) }\end{array}$ \\
\hline $\begin{array}{l}\text { Hill-hole pairs and sediment rafts } \\
\text { (mapped as discrete features } \\
\text { 'Hill-hole pairs' and 'Rafts') }\end{array}$ & $\begin{array}{l}\text { Discrete holes/depressions in the sea floor with } \\
\text { corresponding hills/bumps of similar size or } \\
\text { volume }\end{array}$ & $370 \mathrm{~m}-200 \mathrm{~m}-12 \mathrm{~m}(2 \mathrm{~km}-1.5 \mathrm{~km}-50 \mathrm{~m})$ & $\begin{array}{l}\text { Ice-thrust raft of sediment ripped up from its } \\
\text { bed by slow-flowing, cold-based ice that } \\
\text { transported it further downstream to form a } \\
\text { similar-sized hill }\end{array}$ & $\begin{array}{l}\text { Figs. } 6 \text { A, B; see also } \\
\text { Fig. } 3 \text { in Klages } \\
\text { et al. (2013) }\end{array}$ & $\begin{array}{l}\text { Eastern Svalbard, } \\
\text { Norway (Hogan } \\
\text { et al., 2010, Fig. 3B) }\end{array}$ \\
\hline Crevasse-squeeze ridges & $\begin{array}{l}\text { Highly linear and parallel ridges with identical } \\
\text { slope angles on both flanks }\left(\sim 9^{\circ}\right) \text {, similar } \\
\text { heights but varying lengths }\end{array}$ & $500 \mathrm{~m}-60 \mathrm{~m}-4 \mathrm{~m}(6 \mathrm{~km}-140 \mathrm{~m}-8 \mathrm{~m})$ & $\begin{array}{l}\text { Squeezing of basal till into subglacial crevasses } \\
\text { of overlying ice likely during stagnation phases } \\
\text { transverse to flow }\end{array}$ & $\begin{array}{l}\text { see Fig. } 3 \text { in Klages } \\
\text { et al. (2013) }\end{array}$ & $\begin{array}{l}\text { North of Burke } \\
\text { Island (Klages et al., } \\
\text { 2013, Fig. 3) }\end{array}$ \\
\hline Grooves & $\begin{array}{l}\text { Linear to curvilinear erosional features of } \\
\text { varying lengths }\end{array}$ & $920 \mathrm{~m}-120 \mathrm{~m}-3 \mathrm{~m}(3.2 \mathrm{~km}-240 \mathrm{~m}-8 \mathrm{~m})$ & $\begin{array}{l}\text { Formed by subglacial abrasion and/or erosion } \\
\text { by subglacial meltwater into resistant substrate } \\
\text { formed parallel to flow }\end{array}$ & Fig. 7A & $\begin{array}{l}\text { NE Antarctic } \\
\text { Peninsula shelf } \\
\text { (Reinardy et al., } \\
\text { 2011, Figs. 2, 9) }\end{array}$ \\
\hline Curvilinear iceberg furrows & $\begin{array}{l}\text { Randomly oriented furrows of varying depth } \\
\text { that often cross-cut one another }\end{array}$ & $520 \mathrm{~m}-30 \mathrm{~m}-5 \mathrm{~m}(8 \mathrm{~km}-450 \mathrm{~m}-15 \mathrm{~m})$ & $\begin{array}{l}\text { Result of icebergs that plough into the sea floor } \\
\text { with their keels }\end{array}$ & Fig. 7B & $\begin{array}{l}\text { NE Greenland shelf } \\
\text { (Evans et al., 2009, } \\
\text { Figs. 3B-D) }\end{array}$ \\
\hline $\begin{array}{l}\text { Undifferentiated features } \\
\text { i) Undifferentiated linear bedforms } \\
\text { ii) Sediment lobes }\end{array}$ & $\begin{array}{l}\text { i) Set of crudely-aligned linear ridges and } \\
\text { furrows, linear furrows sometimes have berms } \\
\text { on either side } \\
\text { ii) Fan-shaped stacked sediment lobes }\end{array}$ & $\begin{array}{l}\text { i) } 2 \mathrm{~km}-135 \mathrm{~m}-3 \mathrm{~m}(\geq 8.2 \mathrm{~km}-760 \mathrm{~m}-25 \mathrm{~m}) \\
\text { ii) } \geq 1.8 \mathrm{~km}-470 \mathrm{~m}-3.5 \mathrm{~m} \\
(\geq 2.6 \mathrm{~km}-1 \mathrm{~km}-8 \mathrm{~m})\end{array}$ & $\begin{array}{l}\text { i) Linear scouring of seabed by ice-shelf/iceberg } \\
\text { keels and/or subglacial grooving/ploughing by a } \\
\text { grounded ice sheet } \\
\text { ii) Deposition of glaciogenic debris flow } \\
\text { deposits in front of a palaeo-glacier terminus }\end{array}$ & $\begin{array}{l}\text { i) Fig. } 8 \mathrm{~A} \\
\text { ii) Fig. } 8 \mathrm{~B}\end{array}$ & $\begin{array}{l}\text { i) Pine Island Trough } \\
\text { (Graham et al., } \\
\text { 2010, Fig. 2A) } \\
\text { ii) Spitsbergen, } \\
\text { Norway (Ottesen } \\
\text { et al., 2008, Fig. 8A) }\end{array}$ \\
\hline Featureless/uninterpreted seafloor & $\begin{array}{l}\text { Seafloor showing (i) no notable bedforms or (ii) } \\
\text { features that were not interpreted for this study }\end{array}$ & - & $\begin{array}{l}\text { i) Slow flow of cold-based ice over resistant } \\
\text { substrate, not forming glaciotectonic features } \\
\text { ii)- }\end{array}$ & Fig. $8 \mathrm{C}$ & $\begin{array}{l}\text { NE Antarctic } \\
\text { Peninsula shelf } \\
\text { (Evans et al., 2005, } \\
\text { Figs. 2A, 7D) }\end{array}$ \\
\hline
\end{tabular}




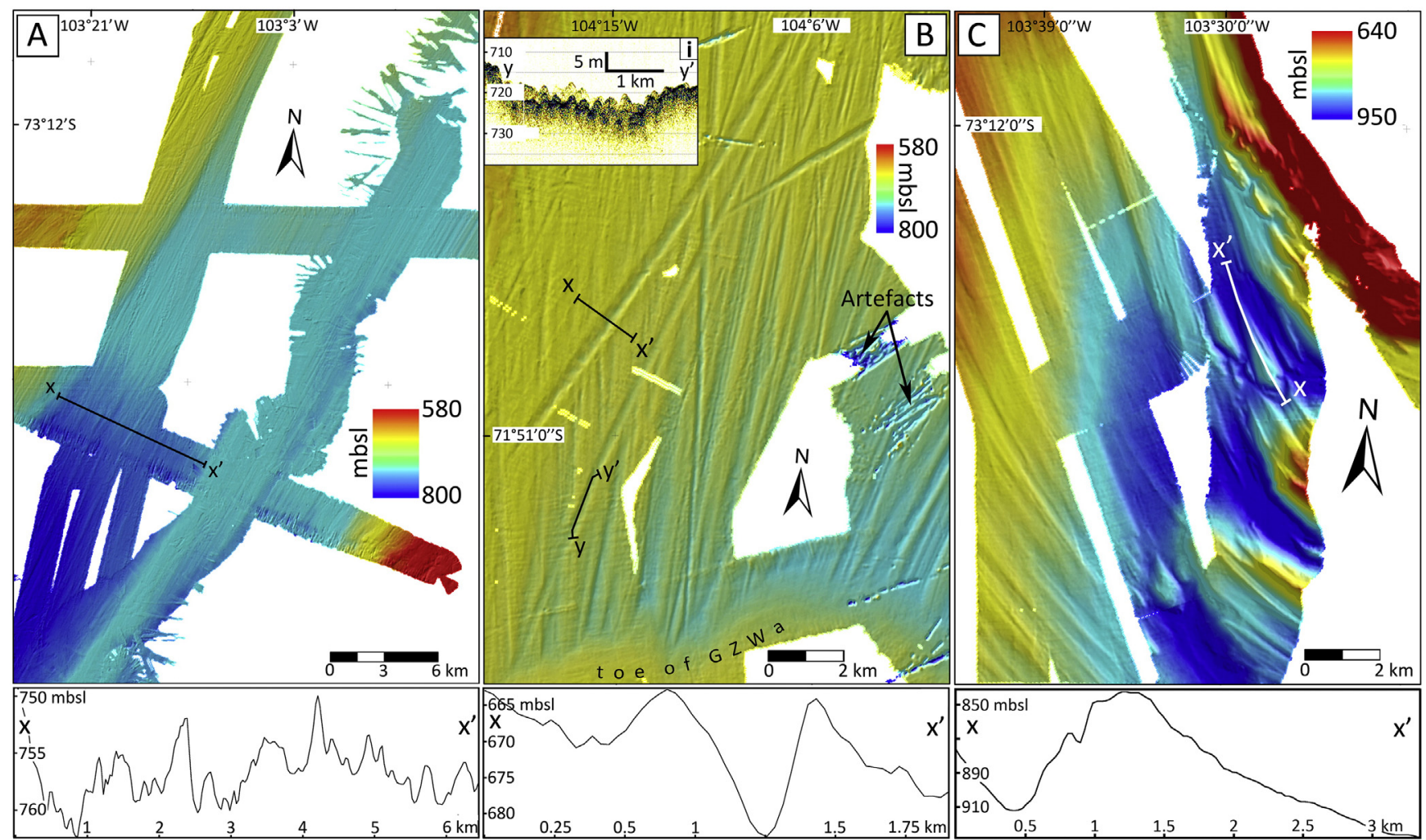

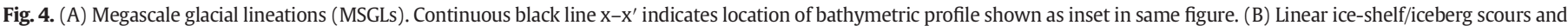

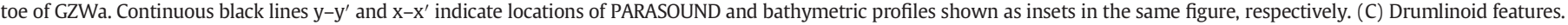
Continuous white line $\mathrm{x}-\mathrm{x}^{\prime}$ indicates location of bathymetric profile shown as inset in the same figure. Grid cell size $30 \mathrm{~m}$. Illuminated from NW (A, B) and NE (C), respectively.

Based on the geomorphology of the linear scours, we suggest that they formed through ploughing by iceberg or sub-ice shelf keels. Because of their greater concordance and generally deeper plough depths, especially when compared to the randomly oriented curvilinear iceberg furrows (see Section 3.2.10), it appears unlikely that the linear scours were produced by free-floating icebergs driven by ocean currents, which would have produced randomly-oriented furrows. Instead, we suggest that the draught of a northward-moving ice shelf or a calved tabular iceberg would have exceeded the local water depth, resulting in scouring of the sea bed by ice keels (e.g., Larter et al., 2012). The linearity of the scours likely results from either the lateral restriction of the thick floating ice by the trough margins or by the persistence of slowly retreating ice on the trough flanks. Furthermore, within the axis of several linear scours, regular-spaced transverse ridges (wave length $\sim 200 \mathrm{~m}$, amplitude 2-3 m) were also identified (Fig. 4B, inset 'i'). Similar corrugations have been mapped beneath the Pine Island Glacier ice shelf and within iceberg scours located in the main PIT. These corrugations are believed to originate from tidally-modulated, periodic keel grounding beneath a seaward-flowing ice shelf (Graham et al., 2013) or at the trailing keel of tabular icebergs (Jakobsson et al., 2011). Jakobsson et al. (2011) and Larter et al. (2012) suggested that icebergs eroding linear, parallel scours may have been embedded within a mélange of sea and brash ice restricting iceberg movement and thus contributed to the linear orientation of the resulting scours as seen here.

\subsubsection{Drumlinoid features}

Because our data do not allow for a clear distinction between drumlins, crag-and-tails, and whalebacks, we summarize any streamlined 'tear-drop' shaped or oval features under the term 'drumlinoid features' (Table 2). In total, 123 individual drumlinoid landforms have been mapped in the study area, found in two prominent clusters (Fig. 4C, mapped in Figs. 2, 3). One of these clusters occurs directly SW of King Peninsula where the amplitudes of individual features range from 18 to $\sim 200 \mathrm{~m}$ (Figs. 3, 4C). Their streamlined, attenuated, and up to $\sim 6-\mathrm{km}-$ long tails point downstream in a NNW direction and often evolve into MSGLs. Consequently, the drumlinoid features are most abundant upstream of the MSGL sets. The second prominent cluster of drumlinoid features is observed directly WNW of the Demas Ice Tongue, while several minor drumlinoid clusters have been identified along the western side of King Peninsula and north of Thurston Island. The latter cluster is the only landform set to occur within a small tributary trough, where bedforms have a westward orientation (Fig. 3). The smallest individual drumlinoid feature has dimensions ( $\mathrm{L}-\mathrm{W}-\mathrm{H})$ of $650-245-15 \mathrm{~m}$ and was detected within a small cluster west of King Peninsula at about $73^{\circ} \mathrm{S}$. Drumlinoid features in our study area, which are generally restricted to the deepest parts of AT, alternate with zones of MSGLs farther downstream (Figs. 2, 3) and are therefore associated with regions of fast palaeo-ice flow (cf., Graham et al., 2009). In some cases the resistance of the subglacial substrate may have controlled bedform formation either by influencing ice flow velocity (e.g., through producing variations in speed) or by providing direct control on the bedforming mechanism at the ice-bed interface (i.e., the ability of ice to erode or shape the geology or to generate a subglacial till layer). This is particularly evident in our study area when the location of the two main clusters of drumlinoid features is compared to seismic data from the corresponding shelf regions. The seismic data reveal bedrock outcrops that likely correspond to indurated sedimentary strata or sedimentary rocks (Uenzelmann-Neben et al., 2007; Hochmuth and Gohl, 2013). We suggest that the drumlinoid features were eroded into this hard sedimentary substrate or have cores formed of this resistant material.

\subsubsection{Grounding-zone wedges (GZWs)}

Based on well-described morphometric characteristics (Table 2), we identified three previously unmapped grounding zone wedges (GZWs) within AT (labelled GZWa-c on Fig. 3), which add to the inventory of Antarctic GZWs recently compiled (Batchelor and Dowdeswell, 2015). 


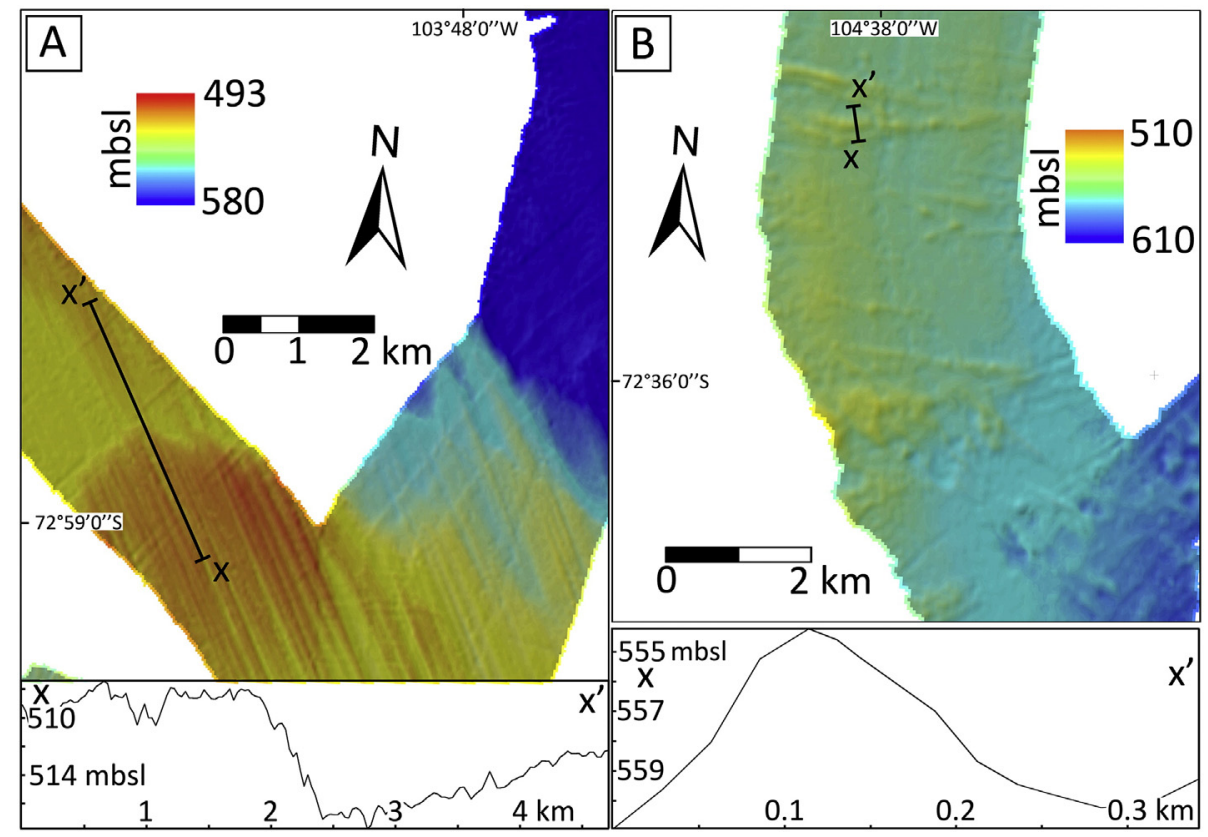

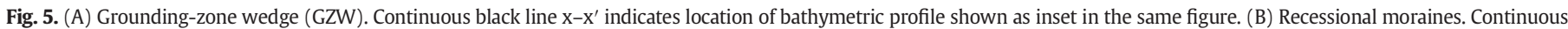
black line $\mathrm{x}-\mathrm{x}^{\prime}$ indicates location of bathymetric profile shown as inset in the same figure. Grid cell size $30 \mathrm{~m}$. Illuminated from NW.

The northernmost GZW (GZWa) is located WNW of Thurston Island directly north of $72^{\circ} \mathrm{S}$, the central GZW (GZWb) is located west of the Demas Ice Tongue, and the southernmost GZW (GZWc) is located between King Peninsula and Burke Island at $73^{\circ} \mathrm{S}$ (Fig. 5A). The GZWa is the most prominent wedge with a length of $\geq \sim 25 \mathrm{~km}$, a width of $\sim 35 \mathrm{~km}$, a height of $\geq 90 \mathrm{~m}$, and a steep lobe-shaped seaward-facing front. Apart from the wedge's toe, GZWb was insufficiently mapped; hence no meaningful dimensions can be provided here. The GZWc (Fig. 5A) has a length of $\sim 28 \mathrm{~km}$, a width of $\sim 11 \mathrm{~km}$, a height of $\sim 10 \mathrm{~m}$, and bears MSGLs on its landward backslope that terminate at the lobate ridge crest. The steeper lee-sides of GZWa and c generally indicate a NNW- to NNE-ward direction of palaeo-ice flow. The GZWs record positions where the grounding lines of former ice streams paused during retreat and subglacial debris was deposited over several centuries to millennia (e.g., Dowdeswell and Fugelli, 2012; Jakobsson et al., 2012). The locations of GZWa and c coincide with outcrops of Cretaceous to Quaternary sedimentary strata that are presumably indurated and thus more resistant to subglacial erosion (Gohl et al., 2013). As the ice margin migrated across these sediments, the presence of a harder bed may have slowed down the grounding line retreat by locally forming a normal, nonlandward sloping bed gradient. Consequently, the accumulation of subglacially advected till at the grounding line may have increased, stabilizing the grounding line against further retreat. The bedrock outcrops (cf., Dowdeswell and Fugelli, 2012) and the subsequent accumulation of large amounts of subglacial debris (cf., Alley et al., 2007) would have counteracted the reverse bedslope within central AT that is generally thought to cause inherent instability of marine-based ice streams (e.g., Joughin and Alley, 2011). Therefore, GZWs are seen as features that help to buffer ice streams against retreat from sea level rise (e.g., Alley et al., 2007), especially at locations where the trough geometry is constricted and/or the resistance of the substrate to subglacial erosion influences the ice stream flow (cf., Gudmundsson et al., 2012; Jamieson et al., 2012; see Section 4.4).

\subsubsection{Ribbed moraine}

A series of large transverse ridges, which were previously interpreted as 'large-scale ribbed moraine' (Klages et al., 2013), occur on a seafloor high north of Burke Island (Figs. 2, 3), which separates the PIT from a tributary trough eroded by the Cosgrove palaeo-ice stream. The large-scale ribbed moraine is similar in form and distribution to a ribbed/rogen moraine (e.g., Hättestrand, 1997; Clark and Meehan, 2001), but its spatial dimensions are considerably larger (Table 2). Our previous work suggested that slowly flowing ice on the inter-ice stream ridge induced long-wave ribbing (wavelength $4.2 \pm 0.1 \mathrm{~km}$ ) of a subglacial stiff till and that the ribbed moraine forms part of a suite of landforms that is diagnostic of slow flow and subsequent stagnation on this part of the shelf (Klages et al., 2013) (see also Sections 3.2.6, 3.2.7, and 3.2.8).

\subsubsection{Recessional moraines}

We mapped two sets of (W)NW-(E)SE-striking 3-15 m high recessional moraines $\sim 18 \mathrm{~km}$ NNE of the ribbed moraine field (Fig. 5B, mapped in Figs. 2, 3; Table 2). Their geometries are similar to those of the recessional moraines overprinting the ribbed moraine north of Burke Island (Klages et al., 2013). A generally steep stoss-side results from subglacial sediments that were extruded or squeezed-out at the ice front and subsequently pushed (N)NE-ward, whereas the gentler lee-side is interpreted to have formed by proglacial gravity flows running down the ice-distal slope (Fig. 5B; following the interpretation of Winkelmann et al., 2010). As the dimensions and orientations of the newly mapped recessional moraines are identical to those reported previously, they are also interpreted to reflect minor re-advances or short stillstands of the grounding line during a general (S)SW-ward retreat across the inter-ice stream ridge north of Burke Island.

\subsubsection{Hill-hole pairs and rafts}

We report 14 hill-hole pairs, which are mainly clustered $\sim 20 \mathrm{~km}$ WSW of the Demas Ice Tongue (Fig. 6B, mapped in Figs. 2, 3; Table 2). In contrast to the three hill-hole pairs from the inter-ice stream ridge (Fig. 3; Fig. 2 in Klages et al., 2013), those WSW of the Demas Ice Tongue are located within the central section of AT and overprint MSGLs (Fig. 6B). Their hills were deposited NNW of the holes, recording a palaeo-ice flow direction consistent with that inferred from the linear bedforms. For the hill-hole pairs on the inter-ice stream ridge, where the hills are generally located NE of the holes, we concluded that a slow and cold-based ice sheet flowing toward the NE had thrust up cohesive sediment from its bed, thereby leaving behind a hole, had entrained and transported the sediment at its base, and subsequently deposited it downstream as a hill (Klages et al., 2013). 


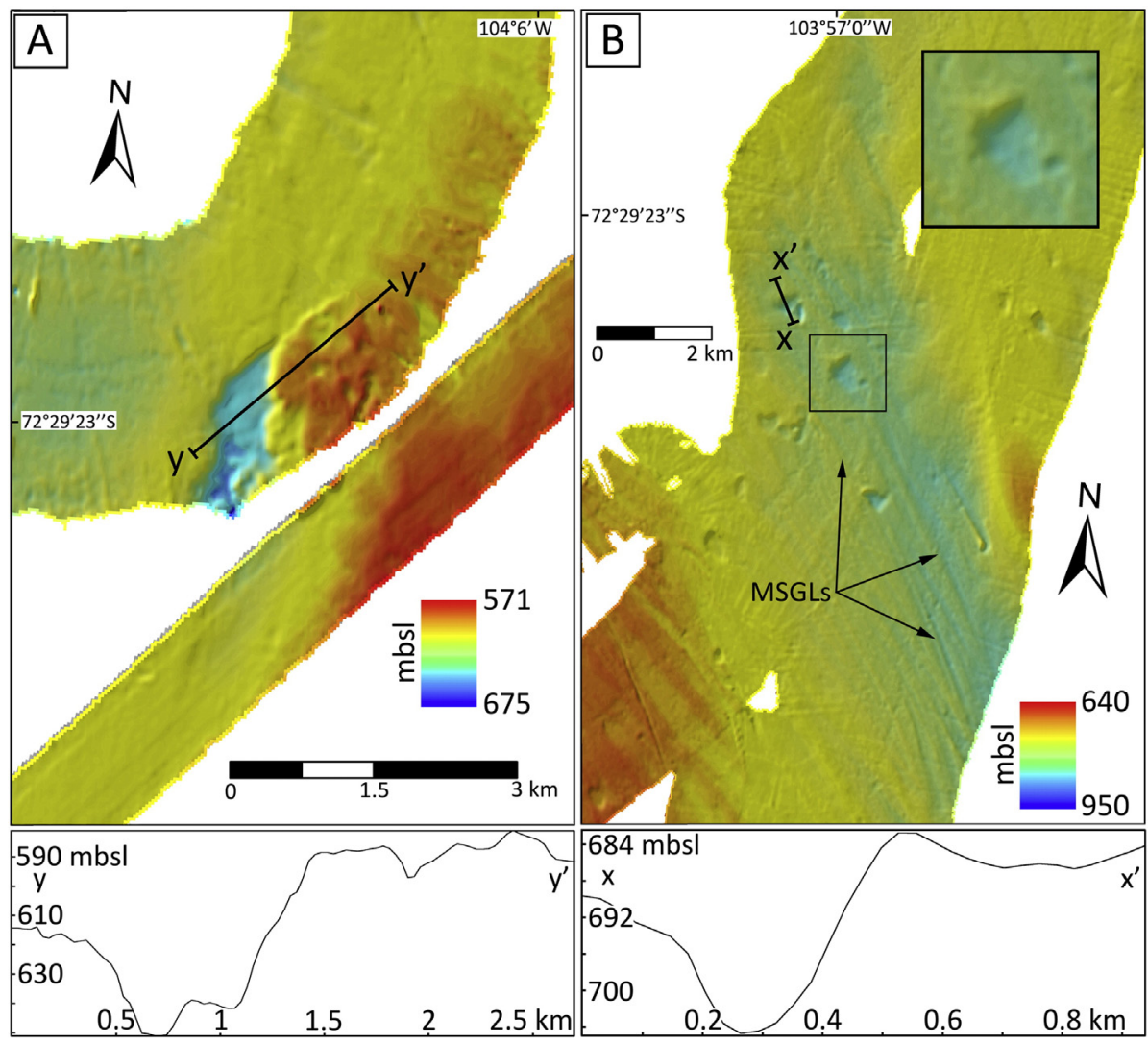

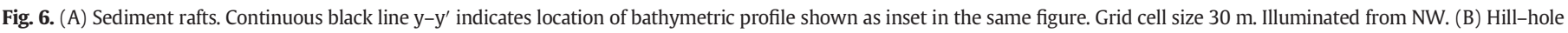
pairs overprinting MSGLs. Grid cell size $30 \mathrm{~m}$. Illuminated from NW. Continuous black line $\mathrm{X}-\mathrm{X}^{\prime}$ indicates location of bathymetric profile shown as inset in the same figure.

Two large sedimentary bodies are observed on the NE side of the inter-ice stream ridge north of Burke Island and WSW of the Demas Ice Tongue (Figs. 2, 3; Table 2). The larger western feature indicates that an $\sim 8$-km-long, $\sim 2.6-\mathrm{km}$-wide, and 20-m-high raft of sediment was dislocated NNE-ward by $\sim 0.5 \mathrm{~km}$. The smaller eastern sediment raft (L-W-H: $1 \mathrm{~km}-1.2 \mathrm{~km}-25 \mathrm{~m}$ ) presumably was dislocated by a similar distance $(\sim 0.6 \mathrm{~km})$ in a NE-ward direction (Fig. $6 \mathrm{~A})$. Both features apparently form intact blocks of seabed, much larger in horizontal width than in height, that seem to have become detached and transported over a short distance as sediment rafts (Fig. 6A). Presumably, these rafts are glaciotectonic features transported by subglacial or marginal mechanical processes (thrusting or freeze-on) (e.g., Evans et al., 2006a). We assume the same formation mechanism for the sediment rafts and the hill-hole pairs, but it is likely that the rafts were transported and deposited largely in stratigraphic cohesion (cf., Vaughan-Hirsch et al., 2011), whereas the sediments forming the hills were possibly faulted and folded and more disturbed. The sediment rafts indicate the same NE-NNE-ward palaeo-ice flow direction as suggested previously for the inter-ice stream ridge (Klages et al., 2013).

\subsubsection{Crevasse-squeeze ridges}

A set of highly linear and parallel symmetrical ridges is also located on the inter-ice stream ridge north of Burke Island (Fig. 3 in Klages et al., 2013). We previously described the 4-8 $\mathrm{m}$ high ridges as crevasse-squeeze ridges and interpreted them to record ice-sheet stagnation following the deposition of the NE set of asymmetric recessional moraines, i.e. the ridges were formed when basal till was squeezed into subglacial crevasses driven by the pressure of the overlying ice (Table 2).

\subsubsection{Grooves}

We mapped 21 linear to curvilinear grooves that occur in two groups at the eastern side of the main trough (Fig. 7A, mapped in Figs. 2, 3). We interpret the grooves to reflect ice stream flow around bedrock highs extending W-ward and NW-ward of Thurston Island and King Peninsula, respectively (Fig. 2). The grooves are aligned to the general palaeoice flow direction recorded by nearby drumlinoid features and MSGLs. In contrast to the latter bedforms, however, the grooves are much shorter ( $\leq 3.2 \mathrm{~km}$ long) and appear to be purely erosive as they cut into an otherwise flat seafloor ( $\leq 8 \mathrm{~m}$ deep) (Fig. 7A; Table 2). Subglacial abrasion and erosion of resistant substrate by subglacial meltwater flow might be responsible for forming the grooves (cf., Lowe and Anderson, 2002; Bradwell et al., 2008) although, based on our limited data coverage, it remains difficult to make a clear distinction between the two erosional processes.

\subsubsection{Curvilinear iceberg furrows}

The majority of the 2001 curvilinear scours interpreted as iceberg furrows have been mapped in the NW part of the study area (Figs. 2, 3 ). They generally occur in the shallowest parts of the shelf and are predominantly NE to NW oriented (Fig. 3). However, individual furrows are multidirectional as a result of the icebergs changing drift direction in response to changes in wind and current directions (Fig. 7B; Table 2). Curvilinear iceberg furrows are most common on seafloor made of soft substrate (e.g., Graham et al., 2009) that is shallow enough to facilitate iceberg grounding. The resulting scours are presumed to obscure other geomorphological evidence for ice sheet presence. However, they were not found on the shallow seabed north of Burke Island presumably because of a substrate resistant to keel scouring, such as bedrock or stiff till (e.g., Klages et al., 2013).

\subsubsection{Undifferentiated features}

3.2.11.1. Undifferentiated linear bedforms. In the NW part of the study area within the extensive fields of curvilinear iceberg furrows, a set of crudely aligned, SSW-NNE-oriented linear ridges and furrows was 


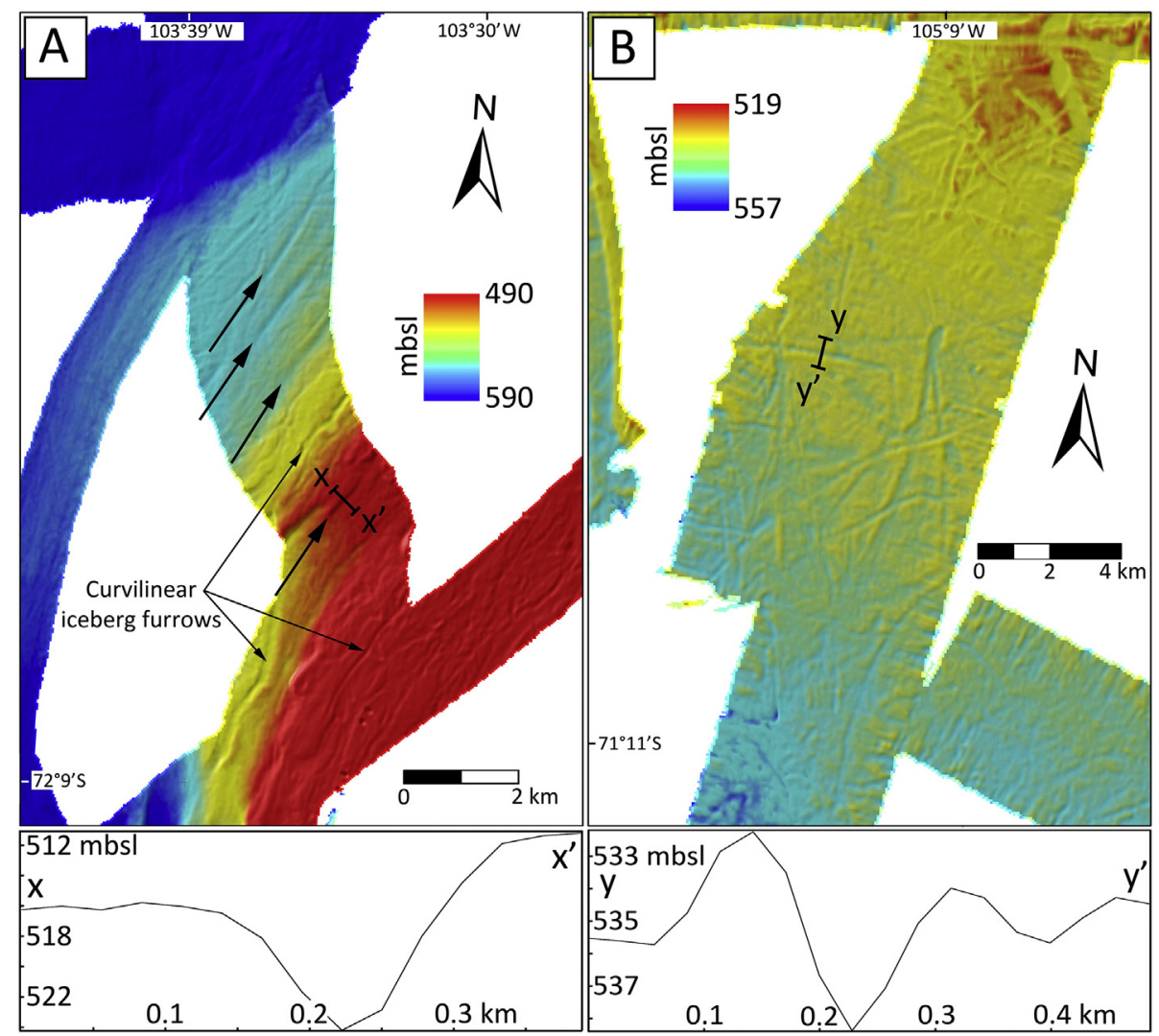

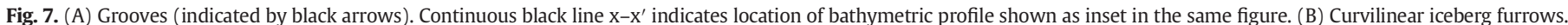
Continuous black line $\mathrm{y}-\mathrm{y}^{\prime}$ indicates location of bathymetric profile shown as inset in the same figure. Grid cell size $30 \mathrm{~m}$. Illuminated from NW.

mapped (Fig. 8A). These elongated ridge/groove features (minimum elongation ratios $\sim 6 / 1-\sim 16 / 1$ ) co-occur with similar elongated, linear V-shaped scours with berms on either side (amplitudes 5-8 $\mathrm{m}$ ). The crudely aligned ridges and furrows are located within a slightly deeper part of the outer shelf ( $600 \mathrm{~m}$ b.s.l.) and extend from $72^{\circ} 0^{\prime} \mathrm{S}$ NNE-ward (Figs. 2, 3). It remains unclear whether the features are incompletely

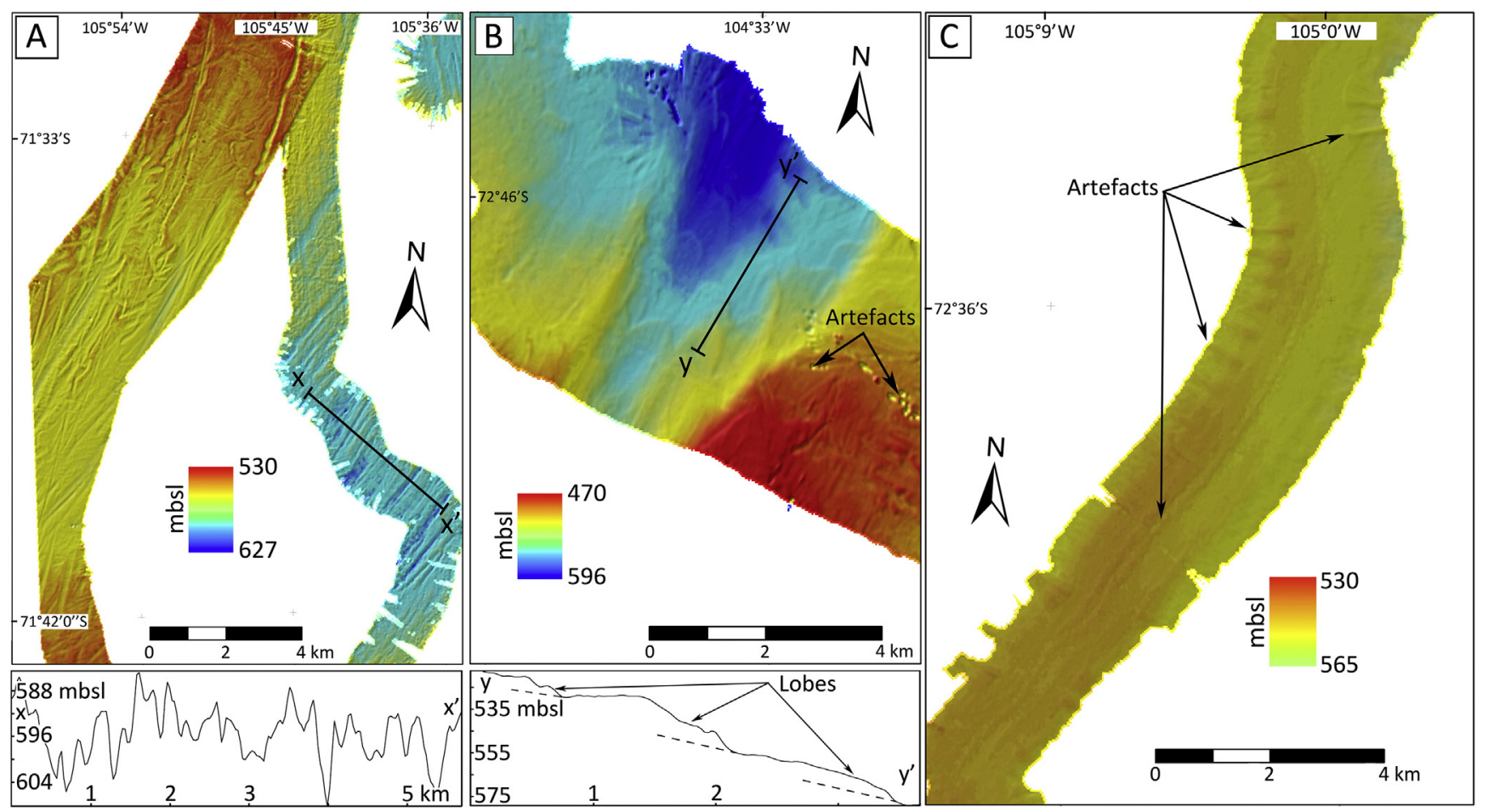

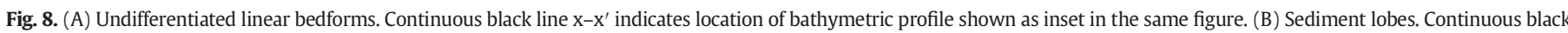
line $y-y^{\prime}$ indicates location of bathymetric profile shown as inset in the same figure. (C) Featureless/uninterpreted seafloor. Grid cell size 30 m. Illuminated from NW. 
mapped MSGLs (Section 3.2.1) or linear ice-shelf/iceberg scours (Section 3.2.2) (Table 2). In the absence of further diagnostic information, we assign them to a bedform class of their own but we recognise that, with better mapping coverage, these features may provide information about former ice flow directions and basal processes.

3.2.11.2. Sediment lobes. Fan-shaped, stacked sediment lobes are observed $\sim 20 \mathrm{~km} \mathrm{NE}$ of Burke Island (Fig. 8B). These features are interpreted to be depositional in origin, as individual lobes clearly lie on top of each other. The lobes point NNE-ward and lie within a small trough that is only slightly deeper than the surrounding seafloor. A lack of data to the SW and NE of the sediment lobes does not allow a clear genetic interpretation of the features, but we propose their deposition by glaciogenic debris flows proximal to a palaeo-glacier terminus as they resemble features reported previously from Spitsbergen fjords (e.g., Plassen et al., 2004; Ottesen et al., 2008; Table 2).

\subsubsection{Zones of featureless seafloor}

Smooth regions of seafloor lacking any notable bedforms occur on the inter-ice stream ridge north of Burke Island (Fig. 8C). Since glaciotectonic bedforms such as hill-hole pairs and sediment rafts are located between these featureless areas (Fig. 3), we infer that any former ice cover here was probably slowly flowing and cold-based. The deposition of a subglacial stiff till recovered nearby in core PS75/234-1 (Klages et al., 2013) also indicates cold-based ice.

Other shelf areas mapped for this study, which do not possess landforms that can be interpreted in terms of ice flow patterns and basal conditions, are located east of AT directly to the W and NW of King Peninsula, to the NW of the Demas Ice Tongue, and to the N and NW of Thurston Island. Rugged to smooth bedrock topography without any overprinting by glacial erosional or depositional processes characterises these areas. We infer that all these areas were also cold-based zones beneath the former ice sheet.

\section{Discussion}

\subsection{Reconstruction of flow pathways and thermal regime}

Generally, subglacial landforms such as MSGLs and drumlinoid features that are aligned parallel to the axis of AT occur within the trough, whereas hill-hole pairs, sediment rafts, moraines, and iceberg scours are located on the shallower inter-ice stream ridges flanking AT (Figs. 2, 3). This distribution enables us to reconstruct regions of fast and slow flow, to differentiate zones of warm- and cold-based ice (Fig. 9), and to set the palaeo-ice flow pattern in our study area into context with flow characteristics in the entire ASE (Fig. 10).

\subsubsection{Indicators for regions of fast palaeo-ice flow}

The presence of MSGLs and elongated drumlinoid features indicate regions of fast ice flow (e.g., Smith et al., 2007; King et al., 2009). Their spatial distribution shows that an ice stream occupied AT in the recent geological past and flowed from south of King Peninsula along its western coast and continued west of the Abbot Ice Shelf, from where it flowed in a NNE-ward direction toward the shelf edge. Bedform evidence reveals that this ice stream was mainly fed by the Cosgrove and Abbot tributaries as well as at least two minor outlets that flowed into the system from King Peninsula in a NW-ward direction and from an area north of Thurston Island in a westward direction, respectively (Fig. 9, black arrows). Fast flow of ice in modern and ancient settings is commonly facilitated by a water-saturated deformable till (e.g., Alley et al., 1987; Ó Cofaigh et al., 2005; King et al., 2009), and areas of MSGLs indicate localities where the ice sheet was warm-based. Our detailed mapping also shows that in regions where the trough width narrows to $\geq 5 \mathrm{~km}$, such as NW of King Peninsula (Figs. 2, 3, 9), the palaeo-ice stream flowed along a curved trough, indicated by sinuous MSGLs. Downstream of the convergence of the Abbot tributary with the Cosgrove tributary diverging ice flow occurred in a widened trough (width $35 \mathrm{~km}$ ). Hochmuth and Gohl (2013) interpreted 'W-shaped' reflections in a seismic profile running in a SSW-NNE direction offshore from the Abbot Ice Shelf front as indication for two individual ice streams that emanated from the present Abbot Ice Shelf (see Fig. 8A in Hochmuth and Gohl, 2013). In contrast, we found geomorphological evidence at the seafloor for only a single tributary, which flowed NW-ward directly southwest of the Demas Ice Tongue during the last maximum ice extent (Fig. 9). From here the merged Abbot and Cosgrove ice streams flowed in a NNE direction onto the outermost shelf to within at least $\sim 10 \mathrm{~km}$ of the shelf edge, where the trough width narrows to $\geq 18 \mathrm{~km}$. Considering that iceberg furrows may have eradicated any MSGLs in the shallow part of AT, directly landward of the shelf break, we assume that the palaeo-ice stream probably extended to the continental shelf edge (Fig. 2, inset in the same figure; cf., Nitsche et al., 2007). Furthermore, we propose that during the last glacial advance the ice stream on the outer shelf north of $72^{\circ} \mathrm{S}$ was considerably wider $(\sim 40 \mathrm{~km})$ than it appears from recorded MSGLs. It likely extended westward as far as $\sim 104^{\circ} 30^{\prime} \mathrm{W}$, as indicated by the presence of GZWa just north of $72^{\circ}$ S. Hochmuth and Gohl (2013) proposed that several small ice streams spread in a radial pattern from Thurston Island in a N-NNE direction across the outermost shelf. In contrast, we only found geomorphological evidence for a single minor ice stream north of Thurston Island (directly west of $101^{\circ} \mathrm{W}$ ) that flowed westward in a $\geq 3-\mathrm{km}$-wide trough. However, owing to a general lack of high-resolution bathymetric data on this part of the shelf and intense iceberg scouring, it remains uncertain whether other small ice streams were present there during the last maximum ice sheet extent. Furthermore, it remains unclear whether the ice within the small trough north of Thurston Island converged with the Abbot-Cosgrove palaeo-ice stream or flowed as a single minor glacier toward the shelf edge (Fig. 9).

\subsubsection{Flow on ice stream margins and inter-ice stream ridges}

On the shallow inter-ice stream ridge north of Burke Island, located between the PIT and AT, an assemblage of sub- and proglacial landforms has been preserved on an otherwise largely smooth seafloor that has been taken to indicate slowly flowing or even, at times, stagnant ice (Klages et al., 2013). In addition to hill-hole pairs, interpreted to record slow and cold-based ice flow (e.g., Ottesen et al., 2005), we also mapped two large sediment rafts $\sim 35 \mathrm{~km}$ WSW of the Demas Ice Tongue (Fig. 3). The formation of glaciotectonic sediment rafts is assumed to be similar to hill-hole pairs, as blocks of highly-resistant material, such as stiff till, are ripped up, entrained subglacially, and transported largely intact further downstream, before they are redeposited in a cold-based marginal zone of a glacier (cf. Evans et al., 2006a). Thus, the sediment rafts add further support to the interpretation of a slow and cold-based NE to NNE-ward ice flow on the inter-ice stream ridge that has been previously inferred from the hill-hole pairs and the ribbed moraine north of Burke Island by Klages et al. (2013) (Figs. 9, 10).

Cold-based regions of modern ice sheets are typically associated with very slow ice flow velocities, whereas warm-based regions are more mobile and fast-flowing sectors of discharge. If we assume that the eastern sediment raft on the inter-ice stream ridge (Figs. 2, 6A) formed simultaneously with the set of NNW-oriented MSGLs located only $\sim 5 \mathrm{~km}$ away, we are able to identify a former boundary between cold- and warm-based regions of the last ice sheet (Figs. 3, 9). This boundary hints at an ice stream marginal shear zone in this region, i.e. the former juncture between the fast-flowing, warm-based ice stream tributary emanating from the modern Cosgrove Ice Shelf and the slowly moving, cold-based ice on the inter-ice stream ridge north of Burke Island (cf., Raymond et al., 2001).

At this stage, we delimit similar basal ice conditions for the remaining marginal- and inter-ice stream areas, which lie in a similar waterdepth range as the inter-ice stream ridge north of Burke Island (Fig. 9), as direct geomorphological evidence for cold basal conditions is lacking because of scouring by iceberg keels (Fig. 3). Therefore, we consider these areas as 'likely cold-based' inter-ice stream ridges 


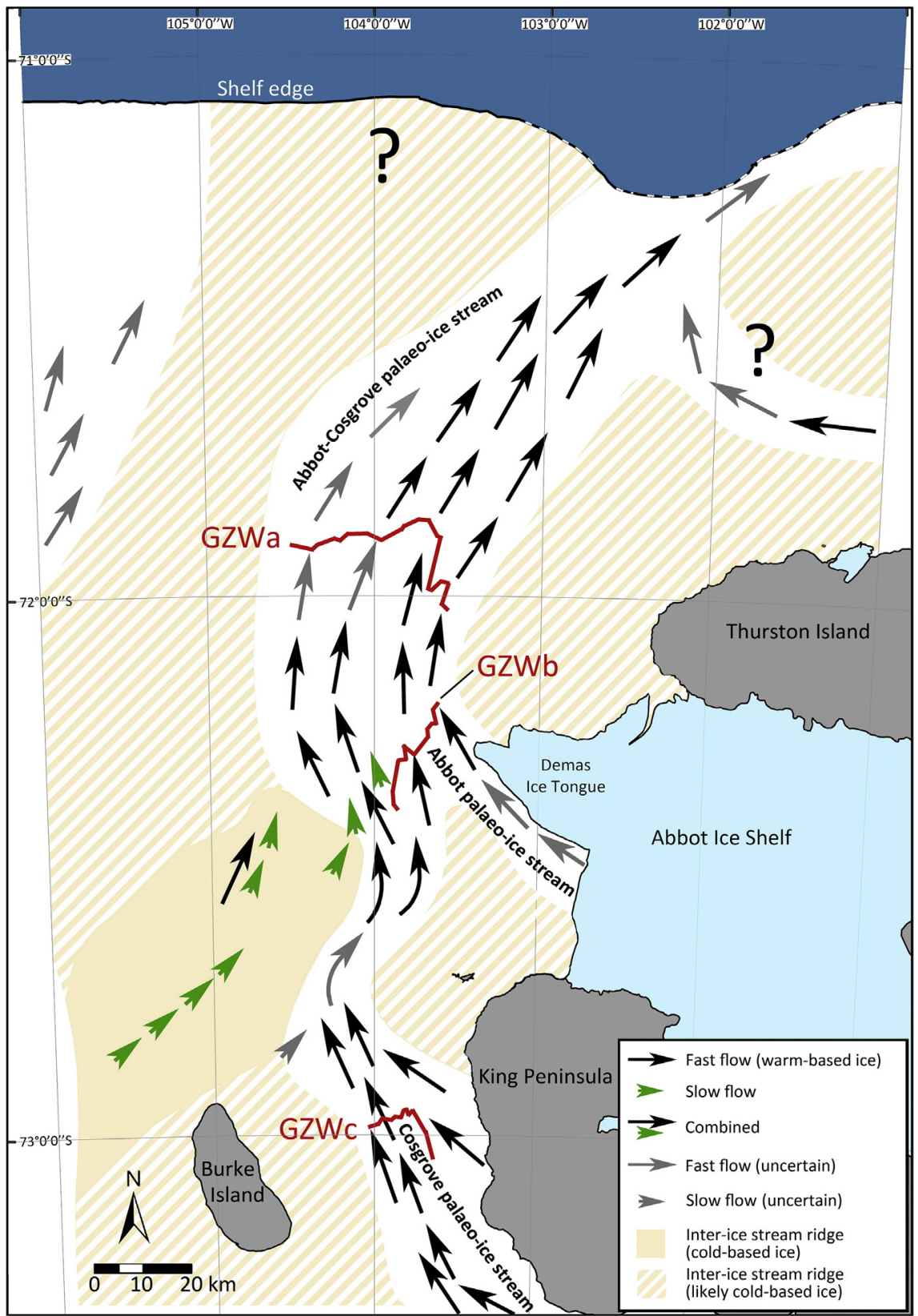

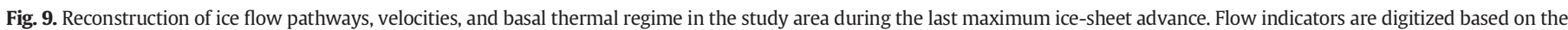

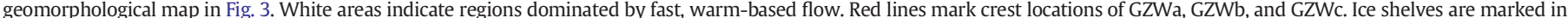

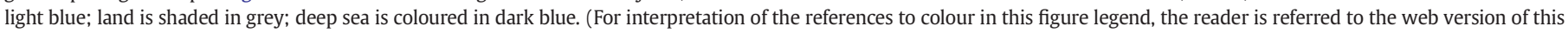
article.).

(Fig. 9) based on the geomorphological evidence nearby. The predominant WSW-ENE orientation of iceberg scours on the inter-ice stream areas of the outer shelf might have been steered by the westwardflowing Antarctic Coastal Current, which controls sea-ice drift in this area today (Assmann et al., 2005).

\subsection{Evidence for past changes in basal conditions}

Our characterisation of cold- and warm-based conditions at the former ice sheet bed is limited by the fact that the preserved geomorphological record is either a snapshot of the last basal conditions just before deglaciation or an integrated record of past basal conditions over time. However, one region in which a clear evolution of basal conditions can be seen is located WSW of the Demas Ice Tongue, where a superimposed assemblage of subglacial landforms is indicative of fast, warm-based (MSGLs) and slow, cold-based palaeo-ice flow (hill-hole pairs) (Figs. 2, 3, 6B). At the seabed, the holes of the glaciotectonic hill-hole pairs clearly overprint the MSGLs, providing a relative chronology that suggests a change in basal thermal regime from warm-based, fast flow to cold-based, slow flow. The downstream deposition of the hills NNW of the holes indicates an identical ice flow direction as recorded by the MSGLs. Consequently, a change in the basal thermal regime from warm- to cold-based conditions must have occurred after the formation of the MSGLs to enable subglacial thrusting by ice that was frozen to its bed forming the hill-hole pairs (cf., Hogan et al., 2010).

Stokes et al. (2008) described a similar succession of bedforms from the NW Canadian Shield, where ribbed moraines overprint MSGLs. This study concluded a significant change in ice flow velocities and in rheology of the subglacial material from water-saturated soft tills, in which the MSGLs had formed, to stiffer more dewatered tills that enabled a 


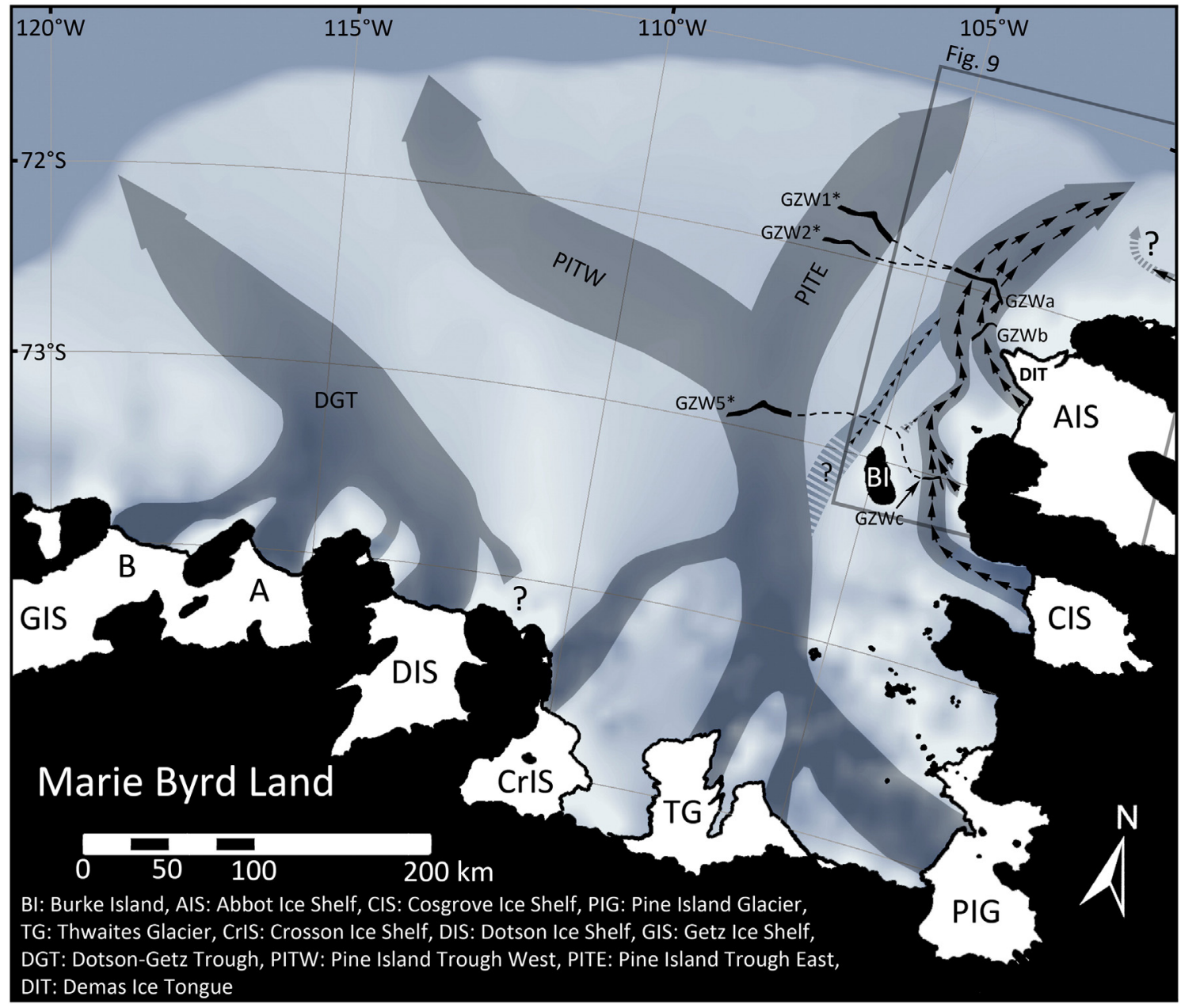

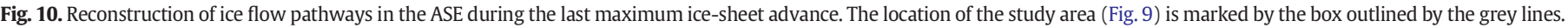

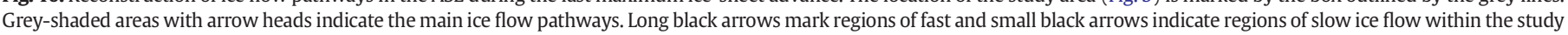

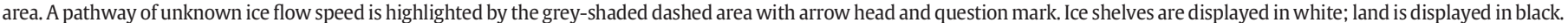
Abbreviations for the main ice shelves and bathymetric troughs are explained in the figure. ( $\mathrm{GZW}$ '1, 2 \& 5': Graham et al., 2010).

ribbed moraine to form under much slower ice flow. We suggest an analogous change, in which subglacially thrust hill-hole pairs formed after a switch in basal conditions of the overlying portion of the ice sheet. As hill-hole pairs have been previously interpreted as features formed near cold-based ice stream margins (e.g., Moran et al., 1980; Evans et al., 2006a), one possibility is that the hill-hole pairs in this area of the ASE shelf reflect the thermal conditions at the bed of the ice stream margin just prior to its landward retreat. Thus, our observation of hill-hole pairs superimposing MSGLs may imply that slow flow and cold-based conditions characterised the final phase of glacial activity in this area. This scenario contrasts with the hypothesis of accelerated flow during post-LGM ice sheet retreat from other parts of the West Antarctic continental shelf (e.g., Mosola and Anderson, 2006; Dowdeswell et al., 2008).

\subsection{Relationships to main palaeo-ice stream flow in PIT}

Several studies have investigated the post-LGM retreat pattern of the WAIS within the main PIT (e.g., Lowe and Anderson, 2002; Evans et al., 2006b; Graham et al., 2010; Jakobsson et al., 2012; Nitsche et al., 2013) and on an adjacent inter-ice stream area (Klages et al., 2013). Both the fast- and slow-flowing parts of the ice sheet in the eastern ASE retreated stepwise, as recorded by five GZWs within PIT and recessional moraines on the inter-ice stream ridge. As part of our mapping, we have documented three discrete GZWs (GZWs 'a-c' in Figs. 3, 9, 10) within AT, of which the two largest (GZWa and c) are located at similar latitudes as GZW1, GZW2, and GZW5 in the eastern branch PIT (Fig. 10; Graham et al., 2010; Jakobsson et al., 2012). This relationship might hint at a related stepped retreat of the ice streams in both troughs, whereby GZW1 and GZW2 in PIT may have formed simultaneously with GZWa in AT (Fig. 10). A coherent grounding line retreat is also indicated by several sets of recessional moraines on the inter-stream ridge between PIT and AT that record a stepwise retreat (Figs. 2, 3), which might also correlate with the formation of GZWc and GZW5 in the neighbouring troughs (e.g., Smith et al., 2014).

As for the overall pattern of ice stream flow in PIT, a direct eastward flow from PIT into AT north of $72^{\circ} \mathrm{S}$ during past glacial maxima has recently been proposed by Hochmuth and Gohl (2013). If the undifferentiated linear bedforms on the outer shelf between $105^{\circ}$ and $106^{\circ} \mathrm{W}$ were crudely aligned MSGLs (Fig. 3; Table 2), a NNE-ward ice flow of the eastern branch of PIT could have been initiated at some point (cf., Fig. 7 in Graham et al., 2010). This potential palaeo-flow pathway, however, does not show a direct relation to the ice flow in AT during the last glaciation, hence no direct connection between the ice streams that flowed through PIT and AT can be inferred from the available geomorphological record (Figs. 2, 3, 9).

\subsection{Relation of GZWs to the subglacial geology}

The GZW5 in PIT formed at a location where the trough width is constricted (bottle neck-effect; see Fig. 5 in Larter et al., 2014) and where a sub-seafloor high probably consisting of hard sedimentary strata resistant to subglacial erosion is located (cf., Gudmundsson et al., 2012; 


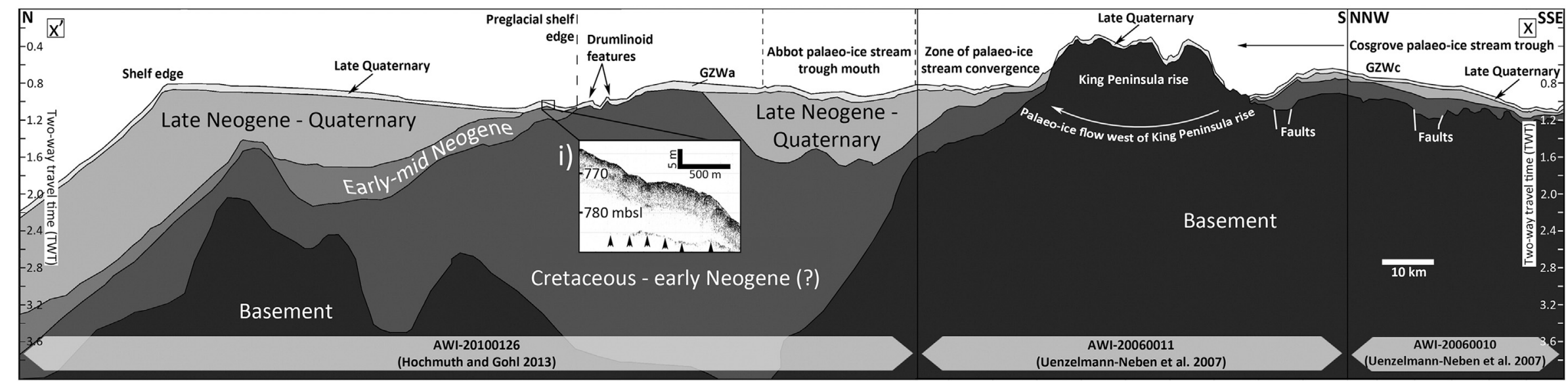

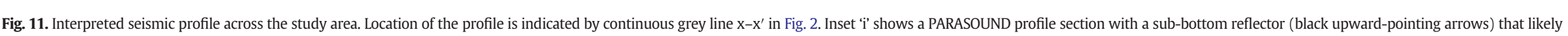
corresponds to the surface of old, hard sedimentary strata of assumed early-mid-Neogene age.

The figure is based on interpretations derived from Uenzelmann-Neben et al. (2007), Gohl et al. (2013), and Hochmuth and Gohl (2013). 
Jakobsson et al., 2012; Jamieson et al., 2014). The grounding lines of ice streams tend to pause on seafloor highs during general retreat that likely act as pinning points on the ice stream bed (Dowdeswell and Fugelli, 2012). The GZWc in AT is located at a trough section constricted by distinct bedrock highs from either side; this bedrock constriction likely served to moderate ice discharge at this location and stabilize the overall retreat. In addition, GZWs a and c are underlain by highs, which consist of old, likely lithified sedimentary strata of assumed Cretaceous to Quaternary age (Gohl et al., 2013; Hochmuth and Gohl, 2013) (Fig. 11). These highs along the ice stream's pathway interrupt the generally reverse bedslope on the shelf and are also likely to have caused the ice stream grounding-line to pause during retreat. Inset ' $i$ ' in Fig. 11 illustrates the proximity of these old sedimentary strata near the modern seafloor directly offshore from GZWa. The old sedimentary strata may be overlain by post-LGM glaciomarine sediments (Hochmuth and Gohl, 2013), but so far, age control from marine sediment cores is lacking. However, we infer that subglacial geological structures played an important role in the pattern of postglacial grounding line retreat across the eastern ASE shelf.

\section{Summary}

- Our new comprehensive mapping (>3000 landforms) from a compilation of multibeam bathymetry data set from the eastern ASE confirms the existence of the $250-\mathrm{km}$-long Abbot Trough (AT). The AT hosted a large ice stream during the last maximum ice-sheet extent, which was mainly fed by the Cosgrove and Abbot tributaries, and reached the shelf edge without a fast-flow connection to PIT.

- Subglacial landforms resolve regions of warm and cold basal thermal regimes on the shelf and allow for the reconstruction of pathways of fast, streaming ice and slow, inter-stream ice in the study area. Furthermore, one area was documented in which the basal thermal regime changed from warm- to cold-based, perhaps just prior to grounding-line retreat.

- Along the palaeo-ice stream pathway W and NW of King Peninsula as well as WNW of the Demas Ice Tongue, three new GZWs were mapped, two of which may correspond to previously mapped GZWs in the Pine Island-Thwaites palaeo-ice stream trough and possibly also to recessional moraines on the inter-ice stream ridge between AT and PIT. If these landforms are coeval, as we suggest, then they indicate a uniform pattern of episodic grounding-line retreat across the eastern ASE following the LGM (e.g., Smith et al., 2014).

- The locations of the northernmost and southernmost GZWs in AT correspond to constrictions in trough width and sub-seafloor highs consisting of hard substrate that is probably resistant to subglacial erosion, such as lithified sedimentary strata and/or bedrock. This relationship suggests a geological control on grounding-line stillstands during ice sheet retreat.

\section{Acknowledgements}

We thank the captains, crews, and scientists who participated in all the research cruises that collected the data for this study. Furthermore, we are much obliged to J.E. Arndt (AWI) for generating an earlier version of the bathymetric grid. This study is part of the Alfred Wegener Institute research programme Polar Regions and Coasts in a changing Earth System (PACES) and the British Antarctic Survey Polar Science for Planet Earth Programme. It was funded by AWI and the Natural Environment Research Council (NERC). F. Nitsche was funded through NSF grant ANT-0838735. Finally, we would like to thank six anonymous reviewers for providing the helpful comments that improved the manuscript.

\section{References}

Alley, R.B., Blankenship, D.D., Bentley, C.R., Rooney, S.T., 1987. Till beneath ice stream B: 3. Till deformation: evidence and implications. J. Geophys. Res. Solid Earth 92, 8921-8929.

Alley, R.B., Anandakrishnan, S., Dupont, T.K., Parizek, B.R., Pollard, D., 2007. Effect of sedimentation on ice-sheet grounding-line stability. Science 30, 1838-1841.

Anderson, J., Jakobsson, M., OSO0910 Scientific Party, 2010. Oden Southern Ocean 0910: Cruise Report. Meddelanden från Stockholms universitets institution för gelogiska vetenskaper 341, p. 134.

Arndt, J.E., Schenke, H.W., Jakobsson, M., Nitsche, F.-O., Buys, G., Goleby, B., Rebesco, M., Bohoyo, F., Hong, J.K., Black, J., Greku, R.K., Udintsev, G.B., Barrios, F., ReynosoPeralta, W., Taisei, M., Wigley, R., 2013. The International Bathymetric Chart of the Southern Ocean Version 1.0 - a new bathymetric compilation covering circumAntarctic waters. Geophys. Res. Lett. 40, 1-7.

Assmann, K.M., Hellmer, H.H., Jacobs, S.S., 2005. Amundsen Sea ice production and transport. J. Geophys. Res. 110, C12013. http://dx.doi.org/10.1029/2004JC002797.

Bart, P., Owolana, B., 2012. On the duration of West Antarctic ice sheet grounding events in Ross Rea during the Quaternary. Quat. Sci. Rev. 47, 101-115.

Batchelor, C.L., Dowdeswell, J.A., 2015. Ice-sheet grounding-zone wedges (GZWs) on high-latitude continental margins. Mar. Geol. 363, 65-92.

Bradwell, T., Stoker, M., Krabbendam, M., 2008. Megagrooves, and streamlined bedrock in NW Scotland: the role of ice streams in landscape evolution. Geomorphology 97, $135-156$.

Carbotte, S.M., Ryan, W.B.F., O'Hara, S., Arko, R., Goodwillie, A., Melkonian, A., Weissel, R.A., Ferrini, V.L., 2007. Antarctic multibeam bathymetry and geophysical data synthesis: an on-line digital data resource for marine geoscience research in the Southern Ocean. U.S. Geological Survey Open-File Report 2007 http://dx.doi.org/10. 3133/of2007-1047.srp002 (1047 p.).

Clark, C.D., 1993. Mega-scale glacial lineations and cross-cutting ice-flow landforms. Earth Surf. Process. Landf. 18 (1), 1-29.

Clark, C.D., 1999. Glaciodynamic context of subglacial bedform generation and preservation. Ann. Glaciol. 28, 23-32

Clark, C.D., Meehan, R.T., 2001. Subglacial bedform geomorphology of the Irish Ice Sheet reveals major configuration changes during growth and decay. J. Quat. Sci. 16, 483-496.

Clark, C.D., Tulaczyk, S.M., Stokes, C.R., Canals, M., 2003. A groove-ploughing theory for the production of mega scale glacial lineations, and implications for ice-stream mechanics. J. Glaciol. 49 (165), 240-256.

Dowdeswell, J.A., Fugelli, E.M.G., 2012. The seismic architecture and geometry of grounding-zone wedges formed at the marine margins of past ice sheets. Geol. Soc. Am. Bull. 124, 1750-1761.

Dowdeswell, J.A., Ottesen, D., Evans, J., Ó Cofaigh, C., Anderson, J.B., 2008. Submarine glacial landforms and rates of ice-stream collapse. Geology 36.

Evans, J., Pudsey, C.J., Ó Cofaigh, C., Morris, P., Domack, E., 2005. Late Quaternary glacial history, flow dynamics and sedimentation along the eastern margin of the Antarctic Peninsula Ice Sheet. Quat. Sci. Rev. 24, 741-774.

Evans, D.J.A., Phillips, E.R., Hiemstra, J.F., Auton, C.A., 2006a. Subglacial till: formation, sedimentary characteristics and classification. Earth Sci. Rev. 78, 115-176.

Evans, J., Dowdeswell, J.A., Ó Cofaigh, C., Benham, T.J., Anderson, J.B., 2006b. Extent and dynamics of the West Antarctic Ice Sheet on the outer continental shelf of Pine Island Bay during the last glaciation. Mar. Geol. 230, 53-72.

Evans, J., Ó Cofaigh, C., Dowdeswell, J.A., Wadhams, P., 2009. Marine geophysical evidence for former expansion and flow of the Greenland Ice Sheet across the north-east Greenland continental shelf. J. Quat. Sci. 23, 279-293.

Favier, L., Durand, G., Cornford, S.L., Gudmundsson, G.H., Gagliardini, O., Gillet-Chaulet, F., Zwinger, T., Payne, A.J., Le Brocq, A.M., 2014. Retreat of Pine Island Glacier controlled by marine ice-sheet instability. Nat. Clim. Chang. http://dx.doi.org/10.1038/ nclimate2094.

Gohl, K., 2007. The expedition ANT-XXIII/4 of the Research Vessel Polarstern in 2006. Berichte zur Polar- und Meeresforschung (Reports on Polar and Marine Research) (557, 166 pp., http://epic.awi.de/26756/).

Gohl, K., 2010. The expedition of the Research Vessel "Polarstern" to the Amundsen Sea, Antarctica. 2010 (ANT-XXVI/3), Berichte zur Polar- und Meeresforschung (Reports on Polar and Marine Research) (617, 173 pp., http://epic.awi.de/29635/).

Gohl, K., Uenzelmann-Neben, G., Larter, R.D., Hillenbrand, C.-D., Hochmuth, K., Kalberg, T., Weigelt, E., Davy, B., Kuhn, G., Nitsche, F.O., 2013. Seismic stratigraphic record of the Amundsen Sea Embayment shelf from pre-glacial to recent times: evidence for a dynamic West Antarctic Ice Sheet. Mar. Geol. 344, 115-131.

Golledge, N.R., Levy, R.H., McKay, R.M., Fogwill, C.J., White, D.A., Graham, A.G.C., Smith, J.A., Hillenbrand, C.-D., Licht, K.J., Denton, G.H., Ackert Jr., R.P., Maas, S.M., Hall, B.L., 2013. Glaciology and geological signature of the Last Glacial Maximum Antarctic ice sheet. Quat. Sci. Rev. 78, 225-247.

Golledge, N.R., Menviel, L., Carter, L., Fogwill, C.J., England, M.H., Cortese, G., Levy, R.H., 2014. Antarctic contribution to meltwater pulse $1 \mathrm{~A}$ from reduced Southern Ocean overturning. Nat. Commun. 5, 1-10. http://dx.doi.org/10.1038/ncomms6107.

Graham, A.G.C., Larter, R.D., Gohl, K., Hillenbrand, C.D., Smith, J.A., Kuhn, G., 2009. Bedform signature of a West Antarctic palaeo-ice stream reveals a multi-temporal record of flow and substrate control. Quat. Sci. Rev. 28, 2774-2793.

Graham, A.G.C., Larter, R.D., Gohl, K., Dowdeswell, J.A., Hillenbrand, C.-D., Smith, J.A., Evans, J., Kuhn, G., Deen, T., 2010. Flow and retreat of the Late Quaternary Pine Island-Thwaites palaeo-ice stream, West Antarctica. J. Geophys. Res. 115, 1-12.

Graham, A.G.C., Dutrieux, P., Vaughan, D.G., Nitsche, F.O., Gyllencreutz, R., Greenwood, S.L., Larter, R.D., Jenkins, A., 2013. Sea-bed corrugations beneath an Antarctic ice shelf revealed by autonomous underwater vehicle survey: origin and implications for the history of Pine Island Glacier. J. Geophys. Res. 118, 1-11. 
Gudmundsson, G.H., Krug, J., Durand, G., Favier, L., Gagliardini, O., 2012. The stability of grounding lines on retrograde slopes. Cryosphere 6, 1497-1505.

Hättestrand, C., 1997. Ribbed moraines in Sweden - distribution pattern and palaeoglaciological implications. Sediment. Geol. 111, 41-56.

Hillenbrand, C.-D., Kuhn, G., Smith, J.A., Gohl, K., Graham, A.G.C., Larter, R.D., Klages, J.P., Downey, R., Moreton, S.G., Forwick, M., Vaughan, D.G., 2013. Grounding-line retreat of the West Antarctic Ice Sheet from inner Pine Island Bay. Geology 41, 35-38.

Hochmuth, K., Gohl, K., 2013. Glacio-marine sedimentation dynamics of the Abbot glacial trough of the Amundsen Sea Embayment shelf, West Antarctica. Geol. Soc. Lond., Spec. Publ. 381.

Hogan, K.A., Dowdeswell, J.A., Noormets, R., Evans, J., Ó Cofaigh, C., 2010. Evidence for fullglacial flow and retreat of the Late Weichselian Ice Sheet from the waters around Kong Karls Land, eastern Svalbard. Quat. Sci. Rev. 29, 3563-3582.

Jakobsson, M., Anderson, J.B., Nitsche, F.O., Dowdeswell, J.A., Gyllencreutz, R., Kirchner, N., Mohammad, R., O'Regan, M., Alley, R.B., Anandakrishnan, S., Eriksson, B., Kirshner, A., Fernandez, R., Stolldorf, T., Minzoni, R., Majewski, W., 2011. Geological record of ice shelf break-up and grounding line retreat, Pine Island Bay, West Antarctica. Geology 39, 691-694

Jakobsson, M., Anderson, J.B., Nitsche, F.O., Gyllencreutz, R., Kirshner, A.E., Kirchner, N., O'Regan, M., Mohammad, R., Eriksson, B.R., 2012. Ice sheet retreat dynamics inferred from glacial morphology of the central Pine Island Bay Trough, West Antarctica. Quat. Sci. Rev. 38, 1-10.

Jamieson, S.S.R., Vieli, A., Livingstone, S.J., Ó Cofaigh, C., Stokes, C.R., Hillenbrand, C.-D., Dowdeswell, J.A., 2012. Ice-stream stability on a reverse bed slope. Nat. Geosci. 5 (11), 799-802.

Jamieson, S.S.R., Vieli, A., Stokes, C.R., Ó Cofaigh, C., Livingstone, S.J., Hillenbrand, C.-D. 2014. Understanding controls on rapid ice-stream retreat during the last deglaciation of Marguerite Bay, Antarctica, using a numerical model. J. Geophys. Res. Earth Surf. 119, 247-263.

Joughin, I., Alley, R.B., 2011. Stability of the West Antarctic ice sheet in a warming world. Nat. Geosci. 4, 506-513.

Joughin, I., Smith, B.E., Medley, B., 2014. Marine ice sheet collapse under way for the Thwaites Glacier Basin, West Antarctica. Science 344, 735-738.

Kellogg, T.B., Kellogg, D.E., 1987. Late Quaternary deglaciation of the Amundsen Sea: implications for ice sheet modelling. Physical Basis of Ice Sheet Modelling, Proceedings of the Vancouver Symposium, pp. 349-357 (Vancouver).

King, E.C., Hindmarsh, R.C.A., Stokes, C.R., 2009. Formation of mega-scale glacial lineations observed beneath a West Antarctic ice stream. Nat. Geosci. 2, 585-588.

Klages, J.P., Kuhn, G., Hillenbrand, C.-D., Graham, A.G.C., Smith, J.A., Larter, R.D., Gohl, K. 2013. First geomorphological record and glacial history of an inter-ice stream ridge on the West Antarctic continental shelf. Quat. Sci. Rev. 61, 47-61.

Klages, J.P., Kuhn, G., Hillenbrand, C.-D., Graham, A.G.C., Smith, J.A., Larter, R.D., Gohl, K., Wacker, L., 2014. Retreat of the West Antarctic Ice Sheet from the western Amundsen Sea shelf at a pre- or early LGM stage. Quat. Sci. Rev. 91, 1-15.

Larter, R.D., Graham, A.G.C., Gohl, K., Kuhn, G., Hillenbrand, C.-D., Smith, J.A., Deen, T.J., Livermore, R.A., Schenke, H.-W., 2009. Subglacial bedforms reveal complex basal regime in a zone of paleo-ice stream convergence, Amundsen Sea Embayment, West Antarctica. Geology 37, 411-414.

Larter, R.D., Graham, A.G.C., Hillenbrand, C.-D., Smith, J.A., Gales, J.A., 2012. Late Quaternary grounded ice extent in the Filchner Trough, Weddell Sea, Antarctica: new marine geophysical evidence. Quat. Sci. Rev. 53, 111-122.

Larter, R.D., Anderson, J.B., Graham, A.G.C., Gohl, K., Hillenbrand, C.D., Jakobsson, M., Johnson, J.S., Kuhn, G., Nitsche, F.O., Smith, J.A., Witus, A.E., Bentley, M.J., Dowdeswell, J.A., Ehrmann, W., Klages, J.P., Lindow, J., Ó Cofaigh, C., Spiegel, C., 2014. Reconstruction of changes in the Amundsen Sea and Bellingshausen Sea sector of the West Antarctic Ice Sheet since the Last Glacial Maximum. Quat. Sci. Rev. 100, 55-86.

LeBrocq, A.M., Bentley, M.J., Hubbard, A.L., Fogwill, C.J., Sugden, D.E., 2011. Reconstructing the Last Glacial Maximum ice sheet in the Weddell Sea embayment, Antarctica, using numerical modelling constrained by field evidence. Quat. Sci. Rev. 30, 2422-2432.

Livingstone, S.J., Ó Cofaigh, C., Stokes, C.R., Hillenbrand, C.-D., Vieli, A., Jamieson, S.S.R., 2013. Glacial Geomorphology of Marguerite Bay Palaeo-Ice Stream, western Antarctic Peninsula. J. Maps 9 (4), 558-572.

Lowe, A.L., Anderson, J.B., 2002. Reconstruction of the West Antarctic ice sheet in Pine Island Bay during the Last Glacial Maximum and its subsequent retreat history. Quat. Sci. Rev. 21, 1879-1897.

Miller, H., Grobe, H., 1996. Die Expedition ANTARKTIS-XI/3 mit FS “Polarstern" $1994=$ The expedition ANTARKTIS-XI/3 of RV "Polarstern" in 1994. Berichte zur Polarforschung (Reports on Polar Research). Alfred Wegener Institute for Polar and Marine Research 188, Bremerhaven (115 pp., http://epic.awi.de/26366/).

Moran, S.R., Clayton, L., Hooke, R.L., Fenton, M.M., Andriashek, L.D., 1980. Glacierbed landforms of the prairie region of North America. J. Glaciol. 25, 457-476.

Mosola, A.B., Anderson, J.B., 2006. Expansion and rapid retreat of the West Antarctic Ice Sheet in eastern Ross Sea: possible consequence of over-extended ice streams? Quat. Sci. Rev. 25, 2177-2196.
Nitsche, F.O., Jacobs, S.S., Larter, R.D., Gohl, K., 2007. Bathymetry of the Amundsen Sea continental shelf: Implications for geology, oceanography, and glaciology. Geochem. Geophys. Geosyst. 8, Q10009. http://dx.doi.org/10.1029/2007GC001694.

Nitsche, F.O., Gohl, K., Larter, R.D., Hillenbrand, C.-D., Kuhn, G., Smith, J.A., Jacobs, S. Anderson, J.B., Jakobsson, M., 2013. Paleo ice flow and subglacial meltwater dynamics in Pine Island Bay, West Antarctica. Cryosphere 7, 249-262.

Ó Cofaigh, C., Pudsey, C.J., Dowdeswell, J.A., Morris, P., 2002. Evolution of subglacial bedforms along a paleo-ice stream, Antarctic Peninsula continental shelf. Geophys. Res. Lett. 29, 1-4.

Ó Cofaigh, C., Dowdeswell, J.A., Allen, C.S., Hiemstra, J.F., Pudsey, C.J., Evans, J., Evans, D., 2005. Flow dynamics and till genesis associated with a marine-based Antarctic palaeo-ice stream. Quat. Sci. Rev. 24, 709-740.

Ottesen, D., Dowdeswell, J.A., Rise, L., 2005. Submarine landforms and the reconstruction of fast-flowing ice streams within a large Quaternary ice sheet: the 2500-km-long Norwegian-Svalbard margin $\left(57^{\circ}-80^{\circ} \mathrm{N}\right)$. Geol. Soc. Am. Bull. 117, 1033-1050.

Ottesen, D., Dowdeswell, J.A., Benn, D.I., Kristensen, L., Christiansen, H.H., Christensen, O. Hansen, L., Lebesbye, E., Forwick, M., Vorren, T.O., 2008. Submarine landforms characteristic of glacier surges in two Spitsbergen fjords. Quat. Sci. Rev. 27, 1583-1599.

Plassen, L., Vorren, T.O., Forwick, M., 2004. Integrated acoustic and coring investigation of glacigenic deposits in Spitsbergen fjords. Polar Res. 23, 89-110.

Pritchard, H.D., Arthern, R.J., Vaughan, D.G., Edwards, L.A., 2009. Extensive dynamic thinning on the margins of the Greenland and Antarctic ice sheets. Nature 461, 971-975.

Pritchard, H.D., Ligtenberg, S.R.M., Fricker, H.A., Vaughan, D.G., van den Broeke, M.R. Padman, L., 2012. Antarctic ice-sheet loss driven by basal melting of ice shelves. Nature 484, 502-505.

Raymond, C.F., Echelmeyer, K.A., Whillans, I.M., Doake, C.S.M., 2001. Ice stream shear margins. In: Alley, R.B., Bindschadler, R.A. (Eds.), The West Antarctic Ice Sheet: Behaviour and Environment. Antarctic Research Series 77. American Geophysical Union, Washington, DC, pp. 137-155.

Reinardy, B.T.I., Hiemstra, J.F., Murray, T., Hillenbrand, C.-D., Larter, R.D., 2011. Till genesis at the bed of an Antarctic Peninsula palaeo-ice stream as indicated by micromorphological analysis. Boreas 40, 498-517.

Rignot, E., Bamber, J.L., van den Broeke, M.R., Davis, C., Li, Y., van de Berg, W.J., van Meijgaard, E., 2008. Recent Antarctic ice mass loss from radar interferometry and regional climate modelling. Nat. Geosci. 1, 106-110.

Rignot, E., Velicogna, I., van den Broeke, M.R., Monaghan, A., Lenaerts, J.T.M., 2011. Acceleration of the contribution of the Greenland and Antarctic ice sheets to sea level rise. Geophys. Res. Lett. 38, L05503. http://dx.doi.org/10.1029/2011GL046583.

Rignot, E., Mouginot, J., Morlighem, M., Seroussi, H., Scheuchl, B., 2014. Widespread, rapid grounding line retreat of Pine Island, Thwaites, Smith, and Kohler glaciers, West Antarctica, from 1992 to 2011. Geophys. Res. Lett. 41, 3502-3509.

Smith, A.M., Murray, T., Nicholls, K.W., Makinson, K., Ađalgeirsdottir, G., Behar, A.E., Vaughan, D.G., 2007. Rapid erosion, drumlin formation, and changing hydrology beneath an Antarctic ice stream. Geology 35, 127-130.

Smith, J.A., Hillenbrand, C.-D., Kuhn, G., Klages, J.P., Graham, A.G.C., Larter, R.D., Ehrmann, W., Moreton, S.G., Wiers, S., 2014. New constraints on the timing of West Antarctic Ice Sheet retreat in the eastern Amundsen Sea since the Last Glacial Maximum. Glob. Planet. Chang. 122, 224-237.

Stokes, C.R., Lian, O.B., Tulaczyk, S., Clark, C.D., 2008. Superimposition of ribbed moraines on a palaeo-ice stream: implications for ice stream shutdown. Earth Surf. Process. Landf. 33, 593-609.

The RAISED Consortium, 2014. A community-based reconstruction of Antarctic Ice Sheet deglaciation since the Last Glacial Maximum. Quat. Sci. Rev. 100, 1-9.

Tinto, K.J., Bell, R.E., 2011. Progressive unpinning of Thwaites Glacier from newly identified offshore ridge: constraints from aerogravity. Geophys. Res. Lett. 38, L20503. http://dx.doi.org/10.1029/2011GL049026.

Uenzelmann-Neben, G., Gohl, K., Larter, R.D., Schlüter, P., 2007. Differences in Ice Retreat across Pine Island Bay, West Antarctica, since the Last Glacial Maximum: indications from multichannel seismic reflection data. U.S. Geological Survey and The Nationa Academies http://dx.doi.org/10.3133/of2007-1047.srp084 (USGS OF-2007-1047, Short Research Paper 084).

Vaughan, D.G., 2008. West Antarctic Ice Sheet collapse - the fall and rise of a paradigm. Clim. Chang. 91, 65-79.

Vaughan-Hirsch, D., Phillips, E., Lee, J.R., Burke, H., Hart, J.K., 2011. Glacitectonic rafting of chalk bedrock: overstand. In: Phillips, E., Lee, J.R., Evans, H.M. (Eds.), Glacitectonics: field guide. Quaternary Research Association, pp. 198-217 (http://nora.nerc.ac.uk/ 16197/1/Overstand.pdf).

Winkelmann, D., Jokat, W., Jensen, L., Schenke, H.-W., 2010. Submarine end moraines on the continental shelf off NE Greenland: implications for Lateglacial dynamics. Quat. Sci. Rev. 29, 1069-1077. 